\title{
Tujejezikovno izobraževanje - analiza potreb in praks tujejezikovnega izobraževanja $v$ slovenski javni upravi
}

\author{
UDK: 37:81'243:35(497.4)
}

\section{Margit Horvath}

Univerza v Ljubljani, Fakulteta za upravo margith.horvath@fu.uni-li.si

\section{Manica Danko}

Univerza v Ljubljani, Fakulteta za upravo manica.danko@fu.uni-li.si

\section{Polonca Kovač}

Univerza v Ljubljani, Fakulteta za upravo polona.kovač@fu.uni-li.si

\section{Janez Stare}

Univerza v Ljubljani, Fakulteta za upravo janez.stare@fu.uni-li.si

\section{IZVLEČEK}

Medtem ko je potreba po tujejezikovnem izobraževanju ter samo izobraževanju postala nuja $v$ večjem delu zasebnega sekłorja, pa je stanje $v$ javni upravi razmeroma nepoznano. Različna mnenja in izkustvene ugotovitve glede potreb po znanju tujih jezikov in jezikovnih zmožnosti (pisanje, govor, poslušanje in branje) javnih uslužbencev na delovnih mestih smo želeli preveriti z raziskavo. Analiza potreb in praks v slovenski javni upravi na področju tujejezikovnega izobraževanja je pokazala, da javni uslužbenci potrebujejo znanje angleščine $(83 \%)$ in nemščine $(68 \%)$, medtem ko so potrebe po znanju francoščine, kljub tesnejšem mednarodnem sodelovanju slovenskih javnih služb $z$ inštitucijami EU

Horvath, M., Danko, M., Kovač, P. \& Stare, J. (2012).

Tujejezikovno izobraževanje - analiza potreb in praks tujejezikovnega izobraževanja v slovenski javni upravi. Uprava X(1), 71-103. 
za dobro četrtino $(26,22 \%)$ manjše od tistih po znanju hrvaščine oz. srbščine, ki jih zaradi priseljevanja državljanov $z$ območja nekdanje Jugoslavije potrebujejo v dobri polovici vprašanih organizacii. Potrebe po znanju tujih jezikov so izražene na različnih mestih: znanje potrebujejo tako vodilni kot tudi svetovalci, višji svetovalci, sekretarii in državni sekretarii ter javni uslužbenci pri uradnem delovanju $s$ tujci in na področju mednarodnega sodelovanja. Vsebinska področja, kjer so potrebe po učenju tujega jezika največje, so povezana s sodelovanjem Slovenije z EU (zaposleni v javni upravi najpogosteje potrebujejo tuji jezik pri prijavah na razpise EU), spremljanju evropske zakonodaje in mednarodnem sodelovanju (npr. vodenje mednarodnih delovnih skupin ali komuniciranje s pobratenimi občinami). Potrebe po znanju tujega jezika so redkeje zaznane na področju pravne stroke, davkov, razvoja stroke, pri protokolu in komunikaciji s strankami iz tujine.

Ključne besede: tuji jeziki, tujejezikovno izobraževanje, javni uslužbenci, potrebe po tujih jezikih

JEL: $100,1121,200$

\section{Uvod}

Znanje slovenskega jezika in tujih jezikov ter ugotavljanje potreb po tem znanju $\vee$ javni upravi postaja vse boli pomembno tako zaradi prenove slovenske javne uprave kot vključevanja $v$ sistem evropske javne uprave. 61. člen Ustave Republike Slovenije določa, da ima vsakdo »pravico, da svobodno izraža pripadnost $k$ svojemu narodu ali narodni skupnosti, da goji in izraža svojo kulturo in uporablia svoj jezik in pisavo«'. Raba tujega jezika pri uradnem delovanju je dovoljena, kadar je $v$ postopku pred državnimi organi in organi samoupravnih lokalnih skupnosti, izvajalci javnih služb ter nosilci javnih pooblastil tuja fizična oseba. Takrat se poleg slovenščine, skladno z zakonom, uporablja tudi tuji jezik. Posebno varstvo uživata madžarščina in italijanščina, ker gre za ustavne kavtele zaščitenih narodnih manjšin (več v Šturm et al., 2011), čeprav je v Sloveniji tem jeziku govorečih razmeroma malo. To izhaja tudi iz predmetne analize, saj se tujejezikovno izobraževanje na območjih občin, kjer sta ta dva jezika tudi uradna (gl. Jerovšek \& Kovač, 2010, str. 101-104), signifikantno ne razlikujejo od potreb drugod. Tuji jezik se tudi uporablja pri mednarodnem sodelovanju javnih služb ter pri nekaterih njegovih drugih

1 Takšen pravni okvir je potrdil tudi Zakon o javni rabi slovenščine (ZJRS), v katerem se v državni upravi, poleg slovenščine kot uradnega jezika, omenja tudi raba madžarščine in italijanščine na območjih manjšin (3. člen) ter drugih tujih jezikov pri uradnem delovanju (5. člen), mednarodnem sodelovanju (6. člen) in poslovanju s strankami (14. člen). 
oblikah, če je tako posebej določeno $v$ področnem zakonu. Pri poslovanju pravnih oseb s strankami na območju Republike Slovenije se dovoljuje raba tujega jezika, kadar javni uslužbenci poslujejo s strankami iz tujine oz. je njihovo poslovanje namenjeno tujcem.

Podpiranje jezikovne raznolikosti je prav eno od načel delovanja EU. Število uradnih jezikov EU se je s širitvama leta 2004 in 2007 povečalo z 11 na $23^{2}$. EU v skladu s svojo jezikovno politiko zahteva, da je njena zakonodaja na voljo $v$ vseh jezikih in tako dostopna vsem državljanom. To pomeni, da lahko predstavniki omenjenih uradnih jezikov $v$ institucijah EU na uradnih zasedanjih komunicirajo $v$ svojem jeziku, $v$ katerega naj bi se tudi prevedli vsi pravni akti, vključno z Uradnim listom EU. Toda zaradi časovne stiske in prevelikih stroškov prevajani se le relativno majhno število uradnih dokumentov prevede $v$ vse jezike. Prevodi so $v$ glavnem $v$ tistih jezikih, v katerih večinoma poteka komunikacija, npr. v Evropski komisiij so to angleščina, francoščina in nemščina. Evropski parlament zagotovi prevod $v$ omenjene tri jezike, medtem ko se dokumenti prevajajo $\checkmark$ druge uradne jezike EU le po potrebi njegovih poslancev.

S članstvom v EU je Slovenija sprejela načela svobodnega gibanja ljudi iz držav članic EU, ki ne potrebujejo delovnih dovoljeni ali dovoljeni za stalno bivanje (Verlič Christensen, 2000, str. 1127). To pomeni, da moramo kot enakopravna članica spoštovati načelo človekovih pravic $v$ zvezi s svobodo gibanja znotraj teritorija držav EU. Poleg tega vsak državljan Evropske Unije lahko $v$ katerikoli državi članici komunicira $v$ svojem oz. kateremkoli drugem uradnem jeziku EU (EC.EUROPA, 2009).

Po podatkih Statističnega urada Republike Slovenije iz poročila o selitvenem gibanju se je število $k$ nam priseljenih tujcer od leta 2000 letno stalno povečevalo, zlasti po letu 2004, ko se je niihovo število letno praviloma povečevalo za okoli $50 \%$. Po letu 2008 pa se je to število v primerjavi s preteklimi leti zmaniševalo. V letu 2009 se je $v$ Slovenijo priselilo 30.296 prebivalcev (to je nekoliko manj kot $v 2008$ ), od tega 27.393 tujcev in 2.903 državljanov Slovenije. Vzrok za to je bila kriza v dejavnosti gradbeništvo, $v$ kateri so se $v$ preteklih letih $v$ največjem številu zaposlovali $k$ nam priseljeni tuji državljani.

2 Angleščina, bolgarščina, češčina, danščina, estonščina, finščina, francoščina, grščina, irščina, italijanščina, letonščina, litovščina, madžarščina, malteščina, nemščina, nizozemščina, poljščina, portugalščina, romunščina, slovaščina, slovenščina, španščina in švedščina. 
Med priseljenimi tujimi državljani v letu 2009 je bilo največ državljanov Bosne in Hercegovine (in sicer 12.900 oz. $47 \%$ vseh priseljenih tujcev). Druga najštevilnejša skupina med njimi so bili državljani Kosova (skoraj 3.600 ali 13,1 \% vseh priseljenih tujcev). Državljani te $v 2008$ na novo nastale države so bili v podatkih za prejšnja leta upoštevani kot državljani Srbije. Kot posledica samostojnosti Kosova se je v letu 2009 ustrezno zmanjšalo število priseljenih državljanov Srbije, ki so bili sicer še $v$ letu 2008 druga najštevilčnejša skupina priseljenih tujcev. V letu 2009 se je tako v Slovenijo priselilo nekaj več kot 2.900 državljanov Srbije ${ }^{3}$. Državljanov drugih držav članic EU pa je bilo v letu 2009 med priseljenimi tujci 1.881, to je $9 \%$ manj kot v letu 2008. Med temi so bili najštevilnejši državljani Bolgarije (539), Italije (271) in Slovaške (208) (Statistični urad, 2011 ).

Potrebe po tujejezikovnem izobraževanju $v$ Sloveniji so se $v$ preteklosti izražale najpogosteje zaradi nekaterih splošnih migracijskih značilnosti Slovenije. Slovenija je že dobrih trideset let pred osamosvojitvijo veljala za pomembno migracijsko območje $v$ nekdanii Jugoslaviii. Takšno vlogo pa je ohranila tudi po prelomnem letu 1991. Med najbolj množične imigrante vse od osamosvojitve sodijo tuji državljani z območja nekdanje Jugoslavije, zlasti iz BIH. Nijm sledijo v različnem vrstnem redu, odvisno od leta, državljani iz nekdanje Srbije in Črne gore, Hrvaške, Makedonije. Med letoma 1996 in 2006 je delež državljanov iz nekdanje Jugoslavije upadel za 5,5 odstotka na račun državljanov iz EU in naslednic SZ. Maja 2006 je Slovenija uveljavila prosto gibanje delavcev državljanov vseh držav EU in Evropskega gospodarskega prostora. Velika večina imigrantov je prišla k nam z namenom zaposlitve ali sezonskega dela, od tega je največ moških. Slovenija je $v$ začetku devetdesetih let podobno kot druge države na vzhodnem obrobju takratne EU postala pomembna prehodna migracijska država. Pri tem je igrala ključno vlogo njena že tradicionalno povezovalna lega med državami Balkana in Srednjo oz. Zahodno Evropo (Komac, 2007, str. 464-467).

Prispevek obravnava analizo in stanje potreb tujejezikovnega izobraževanja z namenom proučitve področja ter opredelitve vrste in intenzivnosti posameznih potreb.

3 Med tujci, priseljenimi v Slovenijo, je leta 2007 bilo 85,4 \% državljanov držav, nastalih na območju nekdanje Jugoslavije: največ iz Bosne in Hercegovine (12.479), Srbije (6.368) ter Makedonije (3.163). 


\section{Javna uprava in tujejezikovne prakse}

Z vidika razumevanja jezikovnih potreb lahko opredelimo različne vrste aktivnosti oz. načine vstopanja $v$ tujejezikovne potrebe. Najpogosteje se izražajo $v$ dejavnostih, kot so npr. turistične, raziskovalne, poslovne (lastništvo nepremičnin, skrbništvo, rejništvo ...) ali delovne (čezmejno opravljanje storitev z napotenimi delavci, sezonsko delo ...). Trajajo različno dolgo, kar pomembno vpliva tudi na aktivnosti tujcev oz. njihovega stika z našo upravo. Med bivanjem v Sloveniji lahko tujec npr. na upravni enoti uredi upravne zadeve na področjih vstopa tujcev $v$ Republiko Slovenijo, bivanja $\vee$ Republiki Sloveniji, integracije, urejanja državljanstva in na področju beguncev in oseb z začasno zaščito. Eden od pogostih vzrokov, da se javna uprava srečuje s tujejezikovnimi potrebami, so imigranti. Velika večina imigrantov je prišla $k$ nam $z$ namenom zaposlitve ali sezonskega dela. (Komac, 2007, str. 466).

Pri komuniciranju uradnih oseb s tujimi strankami, ki niso niti slovensko niti italijansko oz. madžarsko govoreče, lahko pride do težav pri sporazumevanju glede urejanja in reševanja upravne zadeve, če ni zaposlenega $z$ znanjem ustreznega jezika. $\vee$ tem primeru je na voljo več rešitev, ki pomagajo k reševanju nesporazumov zaradi jezikovnih ovir. Tuja (tujejezikovna) stranka lahko s seboj pripelje osebo, katera bo prevajala jezik tujca $v$ slovenski jezik ali tisti jezik, ki ga bo uradna oseba znala aktivno ali pasivno uporabljati.

Poleg omenjenega ni nujno, da izvirajo vsi problemi, povezani z znanjem tujih jezikov, iz uradnega delovanja oz. poslovanja javnih uslužbencev s strankami iz tujine. Do težav lahko pride tudi pri sodelovanju javnih uslužbencev $\vee$ mednarodnih projektih, pri prijavah na EU-razpise ali preprosto pri vsakdanjem prebiranju uradnih dokumentov EU, ki so prevedeni večinoma $v$ angleščino, francoščino ali nemščino in le redko $v$ slovenščino.

\subsection{O kompetencah javnih uslužbencev na področju mednarodnega delovanja}

Kompetenčni model vodenja $v$ državni upravi ${ }^{4}$ sestavlja sedem ključnih kompetenc ${ }^{5}$, ki se nanašajo na tri ravni vodilnih javnih uslužbencev:

$4 \mathrm{Z}$ vidika javne uprave je državna uprava tisti segment slovenske javne uprave, ki odločilno vpliva na spodbujanje in doseganje učinkovitejšega delovanje slovenske javne uprave. 
generalni sekretarji, generalni direktorji direktoratov, direktorji organov $v$ sestavi, direktoriji vladnih služb in načelniki upravnih enot (prva raven), vodje sektorjev in vodje služb (druga raven) ter vodje oddelkov in vodje referatov (tretja raven). Raziskava je pokazala (Stare, 2007), da kompetenčni profil vodenja za vse tri ravni vodenja izkazuje zahteve, ki so pri vseh sedmih kompetencah razmeroma visoke $v$ primerjavi z ocenami vodenja $v$ nekaterih drugih modelih. Med omenjenimi kompetencami je obvladovanje komuniciranja $v$ slovenskem jeziku ena od dimenzij "delovne prožnosti" in predstavlja zmožnost hitre vzpostavitve skupnega jezika s strankami ter izbor komunikacijskih poti, ki vodijo do soglasja in kakovostne storitve.

V današnjem času globalizacije poslovanja in čezmejnih stikov ter zaradi hitrega dostopa in prenosa informacii ima mednarodno sodelovanje vedno večji pomen. Organizacije $v$ javni upravi se na tem področju soočajo z novimi izzivi, za obvladovanje katerih javni uslužbenci potrebujejo druga znanja in veščine od tistih, ki jim zagotavljajo uspešno in kakovostno poslovanje $v$ domačem okolju. Med njimi je znanje tujih jezikov ena od pomembnih kompetenc. To so mehka znanja ${ }^{6}$, ki omogočajo uspeh $v$ današnjih nepredvidljivih časih, ko gre za sodelovanje, posebej majhnih držav, na mednarodnem trgu. Medtem ko so trda znanja (formalna izobrazba) vedno bolj dostopna širokemu krogu, naredijo mehka znanja razliko med ljudmi, ki le znajo, in tistimi ki znajo znanje uporabiti in uveljaviti ter so sposobni uspešne artikulacije svojih znanj (Svetličič, 2011a, str. 123-130). Posebno pomembne so pogajalske veščine, saj so odnosi med podjetji in vladami odnosi moči, kompromisov, sodelovanja in tekmovanja, ker se vse odvija s pogajanji (Svetličič, 2011 b, str. 610). Analiza slovenskega predsedovanja Svetu EU je jasno pokazala, da so najbolj deficitarne mehke veščine, še najbolj znanje angleščine, zatem retorika, sklepanja poznanstev in timsko delo (Svetličič \& Krajnč, 2009 v Svetličič, 2011 a, str. 130).

5 delovna prožnost, ustvarjalnost, vodenje, organizacijsko vzdušje, organiziranje, mreženje in vplivanje ter realizatorske sposobnosti

6 Mehka znanja so osebna, skrita, neformalizirana znanja, ponotranjene veščine (procedure, spretnosti), ki se jih pridobi z izkušnjami in z vajo. Gre za komunikaciiske in pogajalske spretnosti, sposobnost mreženja, lobiranja, znanje jezikov medkulturnega komuniciranja in uporaba in hitrost udejanjanja znanja (gl. Svetličič, 2011 a, str. 125126). 
Javni uslužbenci $v$ mednarodnem sodelovanju so podobni ekonomskim diplomatom, ki igrajo vse pomembnejšo vlogo pri bilateralnem, regionalnem ali multilateralnem uveljavljanju gospodarskih interesov $\mathrm{s}$ ciljem maksimiranja nacionalnih interesov oz. dvigovanja blaginje prebivalcev. Da bi prišli do ustreznih informacii, bi morali poleg strokovnega interdisciplinarnega znanja imeti še komunikacijske veščine $v$ tujem jeziku. Svetličič $(2011 a$, str. 124) ugotavlja, da ima uspešna komunikacija $v$ tujem jeziku neposredno konkurenčno prednost, posebno $v$ stikih s kulturami, ki veliko dajo na svojo identiteto. Tudi skromno znanje jezika domačinov je pogosto lahko vstopnica za poslovanje ali vsaj zelo učinkovit katalizator le-tega in s tem krepitve konkurenčnih prednosti. Obvladovanje medkulturnih razlik postaja ena najpomembnejših kompetenc pri internacionalizaciii (Svetličič, 2011 b, str. 618).

\subsection{Posnetek tujejezikovnega izobraževanja v Sloveniji}

$\checkmark$ zadnjih letih je bilo $v$ Sloveniji na področju poučevanja tujih jezikov stroke na visokošolskih programih narejenih kar nekaj raziskav, ki so se ukvarjale s temami koł so poučevanje nemščine na Univerzi Maribor (UM), Univerzi Ljubljana (UL) in Univerzi na Primorskem (UP) (Grmek \& Rejec 2005), vloga angleškega jezika stroke $v$ prenovljenih bolonjskih programih (Jakoš, 2007), status tujih jezikov stroke in status učitelja tujega jezika stroke v slovenskem visokem šolstvu (Jurković, Djurić \& GodničVičič 2007 in 2008), status tujih jezikov stroke v prenovljenih bolonjskih programih v Sloveniii (Svetlih-Gvardjančič, 2008), pouk nemškega jezika $\checkmark$ okviru boloniske reforme v Sloveniji (Horvath, 2008). Koncem prejšnjega stoletja sta bili še dve raziskavi, ki sta analizirali položai angleščine na članicah Ljubljanske univerze (Čebron, 1998) in vsebino programov za tuji jezik stroke na različnih smereh dodiplomskega študija v Sloveniii (Djurić, 1999). Leta 2008 se je v sklopu Slovenskega društva učiteljev tujega strokovnega jezika (SDUTSJ) oblikovala Skupina za tujejezikovno politiko, ki je pripravila poročilo o tujejezikovnem izobraževanju na vseh ravneh v Sloveniji ${ }^{7}$.

7 Članek skupine za tujejezikovno politiko pri SDUTSJ »Pregled posledic odsotnosti skladne tujejezikovne politike na vseh ravneh izobraževanja $\vee$ RS ter predlogi za izboljšavo ugotovljenega stanja dostopno na http://www.sdutsj.edus.si/tujejezikovna_politika.html, (16. 1. 2012). 


\subsubsection{Učenje tujih jezikov $v$ osnovnih in srednjih šolah (OŠ/SŠ)}

Slovenski vzgojno-izobraževalni sistem predvideva prvi tuji jezik šele v 4. razredu $\mathrm{OŠ}^{8}$. Zaradi tega veliko $O S ̌$ ponuja $v$ lastni režiji tečaje tujih jezikov v prvem vzgojno-izobraževalnem obdobju, ki jih morajo financirati ali vsaj sofinancirati starši. To pomeni, da so nekateri otroci, ne glede na svoje želje, zmožnosti in ambicije diskriminirani zaradi svojega socialnega statusa. Zaradi tega prihaja do že znanega problema t.i. "večnih začetnikov", ki do konca OŠ do štirikrat začnejo z učenjem istega tujega jezika, ne glede na to, kako spretno ga že uporabljajo. Pouk tujega jezika $\checkmark$ OŠ ni dovolj usmerjen $v$ uporabo jezika in koncept zunanjega preverjanja je preveč osredotočen na statično znanje o jeziku in ne na njegovo uporabnost. Prevelike skupine ne omogočajo možnosti notranje diferenciacije.

Učenje tujih jezikov $v$ SŠ je pogosto povezano z podobnimi težavami kot v OŠ. Nekateri učenci, zdaj že dijaki, se ponovno začnejo učiti drugi tuji jezik od začetka, ker nekatere šole ne ponujajo posebnih skupin za nadaljevalce. Od leta 2001, ko je stopila $v$ veljavo reforma poklicnega in strokovnega izobraževanja, ima večina tri- in štiriletnih srednješolskih programov le še en obvezen tuji jezik, nekateri dijaki pa imajo možnost izbire drugega tujega jezika v okrnjenem obsegu. Drugi tuji jezik je obvezen le še $v$ nekaterih strokovnih programih. Tudi gimnazije z zadostnim številom dijakov omejujejo možnosti izbiranja tujih jezikov zaradi organizacijskih, finančnih in kadrovskih razlogov.

\subsubsection{Učenje tujih jezikov na univerzah}

Učenje tujih jezikov na univerzah je tudi povezano z različnimi težavami. Tuji jeziki so $v$ študijskih programih zastopani $v$ različnem skupnem obsegu (od 3 do 14 kreditnih točk), z zelo različno razporeditvijo med kontaktnimi urami in individualnim delom. Opazno je pomanjkanje smernic za sestavo vsebine in posledično poljubnost pri sestavi učnih načrtov. $V$ večini učnih načrtov za tuji jezik nista definirani stopnji izhodiščnega in ciljnega znanja tujega jezika glede na Skupni evropski jezikovni okvir (SEJO). Poleg tega se zdi, da je jezik umeščen v predmetnike precej poljubno, pač glede na razpoložljive/preostale kreditne točke $v$ posameznem semestru/letniku študija. Nadalinji problem

8 Kar je $v$ primerjavi z drugimi evropskimi in nekaterimi jugovzhodnimi državami precej pozno. 
je izguba tujega jezika in še posebej tujega jezika stroke na nekaterih bolonjskih programih $\vee$ primerjavi s starimi univerzitetnimi programi ter dejstvo, da je precej študijskih programov 1. bolonjske stopnje brez tujega jezika.

Večina fakultet ponuja izbiro med dvema tujima jezikoma (angleščino in nemščino), nekatere samo angleščino, redke so fakultete s tremi jeziki ${ }^{9}$. Praviloma je tuji jezik obvezni predmet, ki je na večini bolonjskih programov umeščen le na začetek študija (običajno $v$ prvi letnik) ali pa, kar je še slabše, šele $v$ drugi oz. tretii letnik na 1. bolonjski stopnji študija ali $\vee$ drugi letnik enovitega magistrskega študija in je s tem prekinjena kontinuiteta jezikovnega izobraževanja. Zaradi smernic bolonjskega procesa se število kontaktnih ur ni zvišalo. Pri nekaterih prenovlienih študijskih programih je število ur ostalo nespremenjeno, medtem ko se je pri večini programov znižalo v povprečju za $25 \%$, v nekaterih primerih celo za $65 \%$. Tuji jezik je ponekod tudi izbirni predmet, za katerega se lahko zgodi, da se zaradi premajhnega števila prijav ne izvaja. $\mathrm{Ni}$ natančno določeno, kdaj je to število premajhno. Ponudba je tako videti velika, izvedba pa je večkrat vprašliiva. Premalo je tudi osveščenosti glede koristnosti drugega tujega jezika, saj v nekaterih okoljih angleščina pride mani v poštev kot drugi tuji jeziki.

Zaradi upoštevanja bolonjskih smernic so nujno potrebne spremembe vsebinskega vidika poučevanja tujega jezika stroke. Nekatere spremembe so negativne (npr. izpuščanje tematskih sklopov zaradi krčenja števila kontaktnih ur), lahko pa so tudi priložnost za dvig kakovosti pouka tujega jezika (npr. izbira učnih vsebin v sodelovanju s kolegi drugih strokovnih predmetov, priprava nalog $v$ sklopu e-učenja za spodbujanje samostojnega učenja na področju slušnega in bralnega razumevanja ter pisnega izražanja, uvajanje študij primerov in medkulturnega učenja). $\mathrm{Na}$ univerzah raven vstopnega in izstopnega jezikovnega znanja ni določena, tako da so skupine velikokrat heterogene, izpitni standardi pa odvisni od vsakega učitelja. Skupine po vpisnih podatkih štejejo povprečno od 30 do 50 študentov. Kontaktne ure se delno združujejo na različnih študijskih smereh/programih. Zaradi neustreznega oz. nezadostnega financiranja bolonjskih študijskih programov so fakultete primorane zmanjšati neposredno pedagoško obremenitev učitelja (ne le tujih jezikov), večinoma na račun povečevanja in/ali združevanja skupin in skupnega

9 Fakulteta s tremi jeziki (z dodatno italijanščino) je npr. na UM le ena. 
izvajanja za študente iz več programov. Glede na izvedbo kontaktnih ur je že na ravni učnih načrtov opazna načelna odsotnost standardov, ki določajo velikost skupin. Poleg zmanjšanja kakovosti dela zaradi prevelikih skupin je pereče tudi zmanjševanje števila ur ali opuščanje tujega jezika stroke, ponekod tudi združevanje rednega in izrednega študija oz. tendenca, da bi študenti sami poskrbeli za ustrezno znanje, in sicer na (nekontroliranih, splošnih) tečajih, ki bi jih plačali sami.

\subsection{Pomen večjezičnosti}

$\checkmark$ evropskem prostoru je večjezičnost pogoj za sobivanje različnih narodov in pomembno prispeva $k$ zavedanju o pomenu lastnega jezika $v$ tem prostoru. Večjezičnost pospešuje rabo več jezikov bodisi posameznega govorca ali širše skupnosti in je postala pojav, ki ga narekuje globalizacija. Poenostavlien dostop do informacij prek interneta, izpostavlienost posameznikov različnim jezikom in kulturam, prosti pretok dela in blaga, izobraževanja in bivanja narekujejo veliko potrebo po znanju več jezikov.

Zato so se ministri za šolstvo EU leta 1998 dogovorili, da vse članice EU podprejo večjezičnost in zgodnje učenje tujih jezikov (BMUKK, 2010). Na pomen večjezičnosti opozarja tudi SEJO in poudarja potrebo po načelni spremembi cilja današnjega pouka tujega jezika. Ta naj bi razvijal jezikovni program, $v$ kateremu imajo vse jezikovne kompetence enak pomen. Jezikovna ponudba izobraževalnih ustanov bi morala biti raznolika in učencem omogočiti razvoj večjezičnih kompetenc. Tako bi se povečala jezikovna izkušnja posameznika in izboljšala njegova sposobnost sporazumevanja $v$ tujih jezikih. Večjezičnost tudi prispeva $k$ omejitvi dominantnega položaja angleškega jezika $\vee$ mednarodni komunikaciji (Gl, 2012).

Leta 2000 si je EU postavila cili, da do leta 2010 postane najkonkurenčnejše, dinamično in na znanju temelječe gospodarstvo na svetu. Cilj je doseči večjo socialno kohezijo, trajnostno gospodarsko rast in več delovnih mest. Načrt za dosego tega cilja se imenuje lizbonska strategija in $v$ središču strategije sta politika o izobraževanju in učenje jezikov. Različne strategije, med njimi tudi dokument Sveta Evropske unije »Education and Training 2020« (ET 2020), določajo, da je učenje najmani dveh tujih jezikov ena od temelinih aktivnosti učečih se družb. 
Pomen globalizacije in večkulturnosti je vpet $v$ študijske programe $s$ posameznimi poglavii pri nekaterih strokovnih predmetih, posebej pa se mu posveča poučevanje obeh tujih jezikov (angleščine in nemščine) na Fakulteti za upravo. Učitelji tujih jezikov tesno sodelujejo z mednarodno pisarno pri organizaciji študijskih izmenjav študentov in pedagogov pri razvijanju ozaveščenosti o večkulturnosti. V študijskem letu 2011/12 smo vzpostavili sodelovanje tudi s Francoskim kulturnim centrom in preko nijh organizirali nadaljevalni tečaj francoskega jezika za potrebe internacionalizacije študijske izmenjave oz. sodelovanja s frankofonskimi VŠU.

\subsection{Posnetek obstoječega znanja tujih jezikov}

$\checkmark$ slovenskem izobraževalnem sistemu se splošni angleški jezik poučuje v OŠ v obsegu 650 ur in v SŠ kot prvi tuji jezik (420 ur) ali kot izbirni drugi tuji jezik (200 ur). $\vee$ visokem šolstvu je $v$ študijskih programih najpogosteje zastopan angleški jezik kot jezik stroke. Od študentov v prvem letniku se torej pričakuje, da so dobro podkovani $v$ splošni angleščini glede na predhodno izobrazbo v osnovni in srednji šoli. Zavašnik (2006, str. 5055) navaja, da imajo visokošolske ustanove (VŠU) popolno avtonomijo pri načrtovanju števila ur in vsebine programov angleškega jezika kot jezika stroke. V 90-ih letih so nekatere VŠU celo opustile angleški jezik kot jezik stroke iz študijskih programov, kar je povzročilo nazadovanje pri razvijanju predmetov in znanja jezika pri študentih. Kot je že bilo ugotovljeno na nacionalni ravni ne obstaja dogovor ali jezikovna politika glede tujejezikovnega poučevanja, predvsem na nefiloloških VŠU. Pričakovali bi, da bi na ministrstvu, zadolženem za visoko šolstvo, obstajalo telo, ki bi poskrbelo za interes visokega šolstva po znanju tujih jezikov študentov na mednarodno usmerjenih študijskih programih in izdelalo smernice načrtovanja, ocenjevanja in standardov po kriterijih SEJO. Tako sta načrtovanje in tvorba jezikovnih politik prepuščena posamezni VŠU (celo posameznim učiteljem jezika stroke), kar ne prispeva $k$ poenotenim kriterijem za vrednotenje vstopnega in izstopnega znanja tujih jezikov.

Vstopno znanje tujih jezikov po opravljeni splošni in poklicni maturi se lahko le $v$ grobem ocenjuje po kriterijih SEJO in sicer lahko ocenimo znanje angleškega ali nemškega jezika (kot prvega tujega jezika) 
maturantov splošne mature po kriterijih SEJO z B2 ${ }^{10}$, kar lahko pomeni izhodišče za načrtovanje poučevanja jezika stroke $v$ visokem šolstvu.

Nemški jezik se vse več poučuje kot drugi ali tretji tuji jezik (Gl Ljubljana, 2009), npr. na OŠ kot drugi tuji jezik v okviru izbirnega predmeta tri leta (204 ur), tako da znanje učencev po končani devetletki lahko ocenimo po kriterijih SEJO med $A 1$ in $A 2^{11}$. Tudi $v$ nadaljevanju štiriletne srednje tehnične in poklicne šole oz. gimnazije se dijaki lahko učijo nemščino kot drugi tuji jezik. Po končani srednji šoli imajo gimnazijci za sabo 420 ur pouka nemščine in znanje, ki naj bi ga ocenili po kriterijih SEJO z Bl in B2. Znanje učencev tehnične in poklicne šole je zaradi polovice manj ur jezikovnega pouka slabše, ocenili naj bi ga po kriterijih SEJO med A1 in A2 (Horvath, 2008, str. 372-414).

Jezikovni programi v posameznih VŠU so izdelani na osnovi pričakovani na trgu dela ali bodočih delodajalcev, če jih je mogoče vnaprej predvideti in so bile izdelane analize potreb po znanju tujega jezika po končanem izobraževanju. Tudi Fakulteta za upravo nima izdelane celostne analize potreb, saj je zaposlitev diplomantov fakultete zelo težko vnaprej predvideti, ker so zaposljivi tako $v$ javnem in privatnem sektorju. Po področjih zaposlitve pa je potrebe po znanju tujih jezikov skoraj nemogoče natančno raziskati. Učiteli jezika stroke na Fakulteti za upravo se lahko natančno seznani s študijskimi programi in se poveže s strokovnimi predmeti ter tako usposobi študente na dodiplomskem študiju za uspešno uporabo tujega jezika pri študiju, ki je lahko osnova za rabo kasneje na trgu dela.

\section{Raziskovalni problem}

Izhodišče raziskave je vprašanje, katere potrebe po znanju tujih jezikov (angleškega, nemškega, morebitnega tretjega), glede na jezikovne zmožnosti (pisanje, govor, poslušanje in branje), imajo javni uslužbenci na delovnih mestih. Rezultati raziskave naj bi bili osnova za nadalinji razvoj in posodobitev poučevanja omenjenih jezikov na prvi in drugi stopnji študijskih programov (razvoj kompetenc študentov) ter pripravo ponudbe

10 "Samostojni uporabnik" na višii ravni razume glavne ideje v kompleksnem besedilu tako o konkretnih kot abstraktnih temah, vključno z razpravami s svojega strokovnega področja (gl. MSS, 2011, str. 46).

11 "Osnovni uporabnik" na vmesni ravni se je sposoben sporazumevati v preprostih in rutinskih opravilih, ki zahtevajo preprosto in neposredno izmenjavo informacij o znanih in rutinskih zadevah (gl. MSS, 2011 , str. 46). 
Svetovalno izobraževalnega centra na Fakulteti za upravo Univerze v Ljubljani (kakovostnejše permanentno izpopolnjevanje javnih uslužbencev $v$ slovenskem prostoru).

\subsection{Preliminarno proučevanje}

Preliminarno proučevanje raziskovalnega problema je bilo izvedeno $v$ internem raziskovalnem projektu Fakultete za upravo (Danko, Stare \& Horvath, 2008), kjer so bile raziskane potrebe študentov in diplomatov Fakultete za upravo na področju jezikovnega izobraževanja pri predmetih angleški in nemški jezik. Raziskava je bila izvedena s spletno anketo, raziskane in analizirane so bile potrebe zaposlenih diplomantov po angleškem in nemškem jeziku oz. po morebitnem tretjem tujem jeziku. Namen raziskave je bil pridobitev potrebnih spoznani na osnovi analize učnih potreb diplomantov javne uprave po znanju obeh strokovnih jezikov zaradi sestave kakovostnih študijskih gradiv in priprave stalnega strokovnega jezikovnega izpopolnjevanja zaposlenih. V anketi je sodelovalo 121 anketirancev. Večina anketirancev je bila zaposlena $v$ javni oz. državni upravi, delno tudi v zasebnem sektoriu. Mani kot polovica je opravila maturo iz tujega jezika. Med nijimi je bila večina diplomantov izrednega študija, kar pomeni, da so imeli le tretjino od predvidenih ur za tuji jezik na rednem študiju.

Večina anketirancev je s povprečno dobro oceno zaključila srednješolsko izobraževanje, podobno pa so ocenjevali tudi svoje takratno znanje angleškega in nemškega jezika. Najbolje so ocenili svoje receptivne zmožnosti (poslušanje in branje) in manj produktivne zmožnosti (pisanje in govor). Navedli so, da bi radi izpopolnili svoje samostojno govorno izražanje in sporazumevanje, pisanje, poslušanje in $v$ manjši meri branje. Branje pa še res redko in le kot zahteva delovno mesto uradnika na območjih občin narodnih manjšin. Na delovnem mestu jih je takrat malo uporabljalo tuji jezik, v večji meri le za ustno komunikacijo z nematernimi govorci jezika, pisno je komuniciral le zanemarljiv del anketirancev. Brali so le strokovno literaturo ali poslovno korespondenco, $v$ manjši meri angleške oz. nemške časopise.

Raziskava je še pokazala, da so kot smiselne aktivnosti pri jeziku ocenili predvsem pisanje poslovne korespondence, kratke govorne nastope ter učenje novega besedišča in prevajanje. Navedeno jim je bilo v pomoč pri druženju in sporazumevanju s tujimi poslovnimi partnerii, kot posledico vse večje vloge jezika $v$ poslovnem svetu (seminarii, konference, kongresi). 
Anketiranci so za koristno navedli branje strokovnih časopisov in revii ter študijske literature in poznavanje strokovnih izrazov s področja javne uprave za opravljanje poklica in možnosti nadalinjega študija $v$ tujini. Hkrati pa se jih več kot polovica o tem ni mogla opredeliti, kar si lahko razlagamo, da še niso bili osveščeni glede potrebe znanja tujih jezikov ali zgoli odsotnosti te potrebe na delovnem mestu.

Na osnovi rezultatov ankete smo prišli do zaključka, da bi bilo smiselno organizirati strokovna izpopolnjevanja za različna področja javne uprave ter razvijati jezikovne zmožnosti javnih uslužbencev za potrebe na delovnih mestih. Na tej osnovi je bila izoblikovana tudi potreba po analizi potreb in praks pri tujejezikovnem izobraževanju zaposlenih v slovenski javni upravi.

\subsection{Raziskovalna naloga}

Večjezična ureditev Evropske unije in slovensko vključevanje vanjo sta vzpostavila okvir razvoja, znotraj katerega je $v$ zadnjih desetih letih prišlo do velikih premikov na področju strokovnega jezika in jezikoslovne stroke $\checkmark$ Sloveniii, predvsem glede prevajanja, tolmačenja in terminologije (Erbič, 2008, str. 107). Vključevanje Republike Slovenije v EU, zapis pravnega reda Republike Slovenije $v$ tujih jezikih in iz tega nastajajoče posledice (poslovanje javne uprave z organi EU, drugimi državami oz. njihovimi predstavniki, večji pojav migrantov, komuniciranje z njimi) le še večajo pomen tujejezikovnega izobraževanja $v$ javni upravi.

$Z$ analizo potreb in praks $v$ slovenski javni upravi smo hoteli ugotoviti, kako sta članstvo Slovenije $v$ EU in njena migracijska politika vplivala na potrebe javnih uslužbencev po znanju tujih jezikov, kako zaposleni v javni upravi komunicirajo pri uradnem delovanju in poslovanju s strankami iz tujine in $v$ katerih jezikih se sporazumevajo.

Pri pripravi vprašalnika smo izhajali iz nasledniih hipotez:

- potrebe javnih uslužbencev po znanju tujih jezikov so se po vstopu Slovenije v EU povečale;

- vsebinska področja, kjer so potrebe po učenju tujega jezika največje, so povezana s sodelovanjem Slovenije z EU;

- $\vee$ javni upravi prevladujejo potrebe po znanju angleškega, nemškega in francoskega jezika;

- tuje jezike najboli potrebujejo na ministrstvu za zunanje zadeve;

- znanje tujih jezikov najboli potrebujejo vodilni kadri; 
- organizacije $v$ javni upravi ne financirajo tečajev tujih jezikov;

- potrebe po znanju tujega jezika $v$ javni upravi se razlikujejo med posameznimi statističnimi regijami in organizacijami javne uprave;

- usposabljanje in izpopolnjevanje javnih uslužbencev na področju tujih jezikov ni stalno, sistematično in enotno.

Z raziskavo smo hoteli ugotoviti:

- ali javni uslužbenci pri uradnem delovanju potrebujejo znanje tujega jezika;

- znanje katerih tujih jezikov je najboli potrebno;

- $v$ katerih situacijah se javni uslužbenci najpogosteje srečujejo s tujim jezikom in kako pogosto ga uporabliajo;

- katere jezikovne spretnosti iz tujega jezika javni uslužbenci posebej potrebujejo;

- za katera vsebinska področja obstajajo največje potrebe po tujem jeziku;

- ali se javni uslužbenci redno izobražujejo na področju tujih jezikov;

- kdo (če sploh) financira tečaje tujih jezikov za zaposlene in

- katere organizacije izražajo največjo potrebo po tujejezikovnih izobraževanjih.

\section{Raziskava o stanju in potrebah tujejezikovnega izobraževanja}

\subsection{Potek raziskave}

Za potrebe raziskave je bil oblikovan vprašalnik, namenjen organizacijam javne uprave na območju celotne Republike Slovenije. Enainštirideset vprašani zaprtega in odprtega tipa je bilo namenjeno pridobitvi splošnih podatkov o organizacijah, podatkov o potrebi javnih uslužbencev po znanju tujega jezika pri opravljanju delovnih nalog in podatkov o izvedbi in financiranju tujejezikovnega izobraževanja ter vplivu znanja tujega jezika na kakovost storitev. Pred izvedbo raziskave je bila opravljena "pilotska raziskava" $v$ kateri sta sodelovali ena upravna enota in ena občinska uprava. Rezultati so pripomogli k jasnosti vprašalnika.

Vzorec anketirancev je bil oblikovan na način, da so bila zajeta vsa področja javne uprave. Na tak način je bilo $v$ raziskavo vključenih 
441 organizacii javne uprave. Anketni vprašalnik je bil naslovljen na ministrstva (15), organe $v$ sestavi ministrstev (40), upravne enote (58), vladne službe (16), občinske uprave (210) in nosilce javnih pooblastil (ZPIZ (9), ZZZS (10), zavod za zaposlovanje (12), zavod za šolstvo (9) ter centre za socialno delo (62).

$\mathrm{Na}$ podlagi stroškovne in časovne analize smo se odločili za spletno anketiranje. Glede na razpoložljiva finančna sredstva drugačen način anketiranja (na primer po pošti ali osebni intervju) ni bil smiselno izvedljiv. Čeprav smo se zavedali pomanjkljivosti spletnega anketiranja, pri katerem se po dosedanjih izkušnjah dosega nizka stopnja realizacije vzorca, smo ocenili, da lahko računamo z realizacijo med 10 in 30 odstotkov vrnjenih in izpolnjenih vprašalnikov. Hkrati smo predvidevali, da nam takšen vzorec lahko zagotovi podlago za sklepanje o reprezentativnosti na ravni posameznih regii, segmentov ali organizacij v javni upravi.

Z dobro tretjino naključno izbranih anketirancev smo opravili tudi telefonski razgovor, jim predstavili namen in cilje projekta ter jih zaprosili za sodelovanje. Povezava na vprašalnik je bila posredovana po elektronski pošti. Anketiranje je trajalo dva meseca (od 13. januarja do 13. marca 2009), v tem času pa smo prejeli 103 izpolnjene spletne vprašalnike, kar pomeni 23,35 \% realizacijo vzorca.

Ugotavljamo, da je bil vzorec respondentov (glede na število vseh organizacii javnega sektorja) sicer majhen, vendar raznovrsten. Prav to pa omogoča smiseln prikaz trendov tujejezikovnega izobraževanja na širšem področju javnega sektorja.

Podatke od vseh vprašanih smo zbrali le $v$ prvem delu vprašalnika, medtem ko so $v$ drugem delu anketiranci odgovarjali zelo različno. Npr. na vprašanje o vsebinskih področjih, kjer so največje potrebe po učenju tujega jezika stroke, so odgovorili vsi anketiranci (103). Na vprašanja o potrebah po znanju tujega jezika in nekaterih splošnih podatkih o tujejezikovnem izobraževanju smo prejeli odgovore od 15,19\% (67) vprašanih. Na nekatera vprašanja o poteku tujezikovnega izobraževanja pa odgovore od 4,76\% (21) anketirancev. V tretjem delu vprašalnika nismo prejeli odgovorov od slabe tretjine anketirancev. Npr. na vprašanje o financiranju tujejezikovnega izobraževanja smo prejeli 14,51\% (64) odgovorov in o razlogih za potrebe po tujejezikovnem izobraževanju $15,19 \%$ (67) odgovorov. Zato je v podrobnejši analizi podatkov mogoče zaslediti tri različna števila zbranih odgovorov. 
Spletni vprašalnik so izpolnjevali zaposleni na različnih delovnih mestih. Med njimi je največ višjih svetovalcev (27\%), vodij (17\%), direktorjev (14\%) in svetovalcev (11\%) za različna področja, ter $5 \%$ tajnic in $4 \%$ podsekretarjev. Primerjava med prvo in drugo delovno nalogo teh oseb ne kaže posebnih razlik. Večina je pristojna za vodenje in organizacijo dela (npr. $v$ okviru prve delovne naloge $27,18 \%$ in $v$ okviru druge 10,67\%). 10,67\% jih opravlja kadrovske zadeve, 9,70\% jih koordinira in nadzoruje delo sodelavcev, 5,83 \% jih skrbi za izobraževanje in 4,85\% za mednarodno sodelovanje.

Dobra polovica anketiranih organizacii ima mani kot 50 zaposlenih. Največ $(21,35 \%$ ) jih zaposluje med 20 in 30 javnih uslužbencev; 16,5\% med 10 in $20 ; 7,76 \%$ med 30 in 40 ter $3,88 \%$ med 40 in 50 uslužbencev. Medtem ko 13 organizacii $(12,62 \%)$ ima manj kot 10 zaposlenih, jih $39(37,86 \%)$ ima več kot 50 , od tega $12(11,65 \%)$ med 50 in 100; $6(5,82 \%)$ med 100 in 200; $11(10,67 \%)$ med 200 in 300 in 10 organizacij $(9,7 \%)$ nad 300 zaposlenih.

Po zaključenem spletnem anketiranju je bila najprej opravljena evalvacija rezultatov s pomočjo programa Excel. Ker program ni bil primeren za izračun dodatnih korelacij med različnimi vprašanji, smo opravili še dodatno evalvaciio s statističnim programom SPSS.

Kljub relativno nizki stopnii realizacije vzorca $(23,35 \%)$, smo na osnovi prejetih in izpolnjenih vprašalnikov dobili podlago za sklepanje o njegovi reprezentativnosti glede na tujejezikovno politiko $v$ večjem delu javne uprave in glede na povprečne potrebe po znanju tujih jezikov glede na večii del javnih uslužbencev. Čeprav je raziskovalni vzorec nižji od 30 odstotkov ${ }^{12}$, lahko nakazuje na situacijo in potrebe na področju organizacije in izvedbe tečajev tujih jezikov $v$ večjem delu javnega sektorja. Res pa je, da zaradi precej nizke stopnje sodelovanja pri raziskavi nimamo podlage za verodostojno sklepanje o reprezentativnosti vzorca za posamezne statistične regije ali organizacije, ki so relativno majhne in so $v$ vzorcu zastopane z zelo nizkimi absolutnimi številkami (npr. izpolnjen vprašalnik smo prejeli le od ene izpostave ZZZS) ali sploh niso zastopane (od ZPIZ-a in Zavoda za zaposlovanje nismo prejeli nobenega vprašalnika).

12 Tudi po Medvešek in Hafner Fink v prispevku "Opis poteka raziskave percepcije slovenske integracijske politike« je bila pričakovana realizacija njihove raziskave približno tridesetodstotna (Komac, 2007, str. 482). 


\subsection{Povzetek glavnih ugotovitev}

Raziskava je pokazala (prim. grafikon 1), da javni uslužbenci, poleg redkih formalnih zahtev sistemizacije na območjih občin, kjer bivata avtohtona italijanska in madžarska narodna skupnost (Šturm et al., $2011)^{13}$, pri svojem delu potrebujejo znanje angleškega (83\%) in nemškega jezika (68 \%). Potrebe po znanju francoščine so kljub tesnejšem mednarodnem sodelovanju slovenskih javnih služb z institucijami EU za $26,22 \%$ manjše od potreb po znanju hrvaščine ali srbščine, ki jih zaradi priseljevanja državlianov z območja nekdanje Jugoslavije potrebujejo javni uslužbenci v dobri polovici organizacii.

\section{Grafikon 1: Potrebe javnih uslužbencev po znanju tujih jezikov}

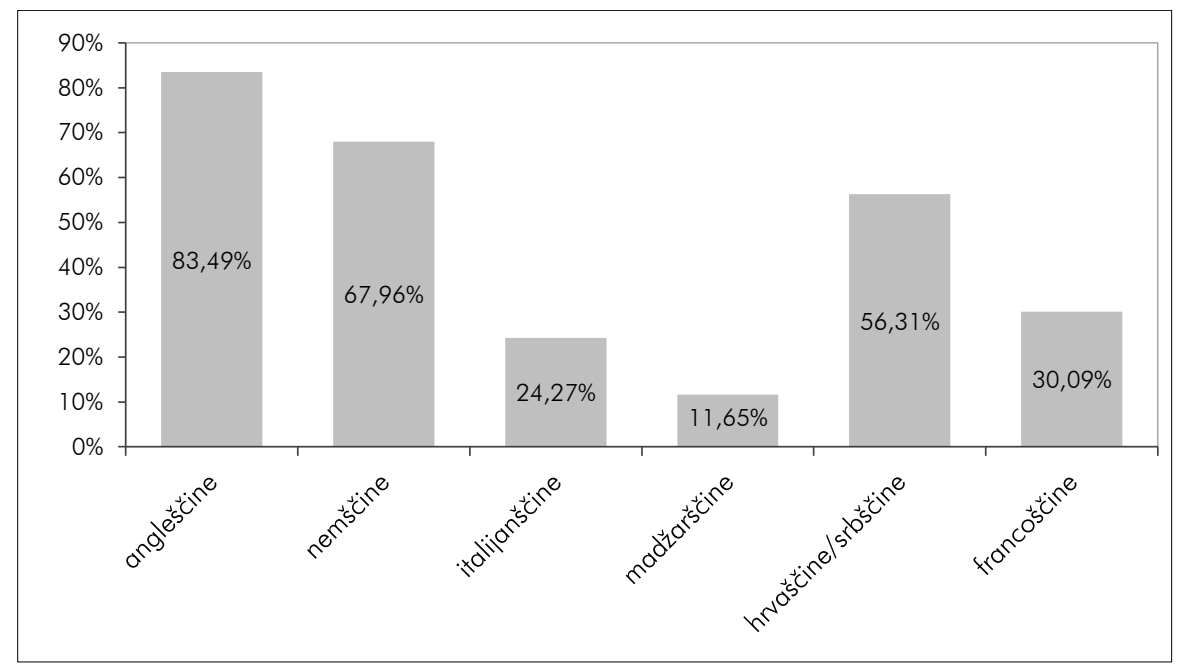

Vir: Anketa, 2009

13 Procesna pravila o rabi jezika $\vee$ postopku so izvedena iz ustavnih določb o uradnem jeziku (11. člen Ustave Republike Slovenije) in pravice do uporabe lastnega jezika in pisave (62. člen). Zato se upravni postopek vodi v slovenskem jeziku, na območjih občin, kjer živita italijanska in madžarska narodna manjšina, pa pod pogojem, da je v tem jeziku vložena vloga oz. stranka uporablja italijanski ali madžarski jezik, tudi v italijanščini in madžarščini. Zato se vloge vlagajo $v$ slovenskem, italijanskem ali madžarskem jeziku tudi izven dvojezičnega območja (gl. peti odstavek 65. člena ZUP), vendar organi izven tega območja poslujejo izključno $v$ slovenskem jeziku, $s$ tem da pripadnikom manjšine zagotavljajo izvrševanje zakonske pravice na način, da na breme stroškov organa poskrbijo za prevod vlog in omogočijo spremljanje postopka na ustni obravnavi prek tolmača. $V$ skladu s pravili o uradnem jeziku se vsem, ki ne znajo uradnega jezika, zagotavlja pravica do spremljanja postopka po tolmaču. Organ ni dolžan prevajati uradnih pisanj, razen če tako določa področni zakon, npr. zakon o tujcih iz leta 2011, po katerem se tujcu vroči odločba o vrnitvi, kjer morata biti izrek in pouk prevedena vsaj v pet jezikov (Kovač et al., 2012). 
Potrebe javnih uslužbencev po znanju angleščine in nemščine se razlikujejo po obsegu. Zaposleni v organizacijah $(39,80 \%$ ali 41$)$ z do 10 zaposlenimi imajo večje potrebe po znanju nemščine kot angleščine $(25,24 \%$ ali 26$)$. Gre za organizacije v javni upravi kot so manjše občine in upravne enote iz Podravske (14,60 \%), Gorenjske (12,60 \%) in Koroške regije (7\%), ki so izpolnili vprašalnik in se nahajajo $\vee$ bližini avstrijske meje. Organizacije z nad 30 zaposlenimi (npr. ministrstva in organi $v$ sestavi ministrstev) imajo za polovico več potreb po znanju angleščine (14\%) kot nemščine (7\%). Pri organizacijah z 10 do 20 oz. 20 do 30 zaposlenimi ni večjih razlik med potrebami po obeh jezikih (10,67\% angleščini, 9,70 \% nemščini).

\section{Grafikon 2: Potrebe po znanju angleškega in nemškega jezika}

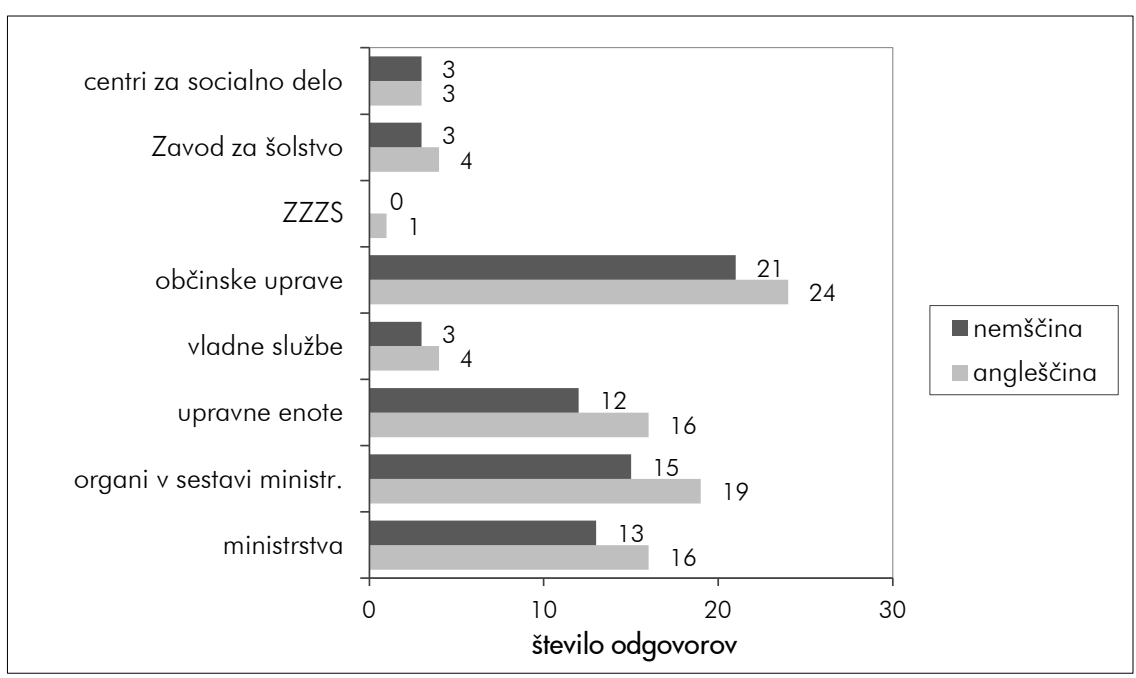

Vir: Anketa, 2009

Potrebo po znanju angleškega oz. nemškega jezika (grafikon 2) najpogosteje izražajo uslužbenci zaposleni v organih v sestavi ministrstva (100\% angl. in 78,94 \% nem.), na ministrstvih $(94,11 \%$ angl. in 76,47\% nem.), občinskih upravah $(85,71 \%$ angl. in $75 \%$ nem.) in upravnih enotah (80\% angl. in $60 \%$ nem.). Najmanjše potrebe so na centrih za socialno delo in Zavodu za zdravstveno zavarovanje (ZZZS).

Z vidika proučevanja tujejezikovnih potreb je bilo ugotovljeno (grafikon 3), da znanja tujih jezikov ne potrebujejo le vodilni kadri, temveč tudi svetovalci, višji svetovalci, sekretarji in državni sekretarji ter javni uslužbenci pri uradnem delovanju s tujci in zaposleni na področju mednarodnega sodelovanja. 
Grafikon 3: Potrebe po znanju tujih jezikov glede na delovni položaj

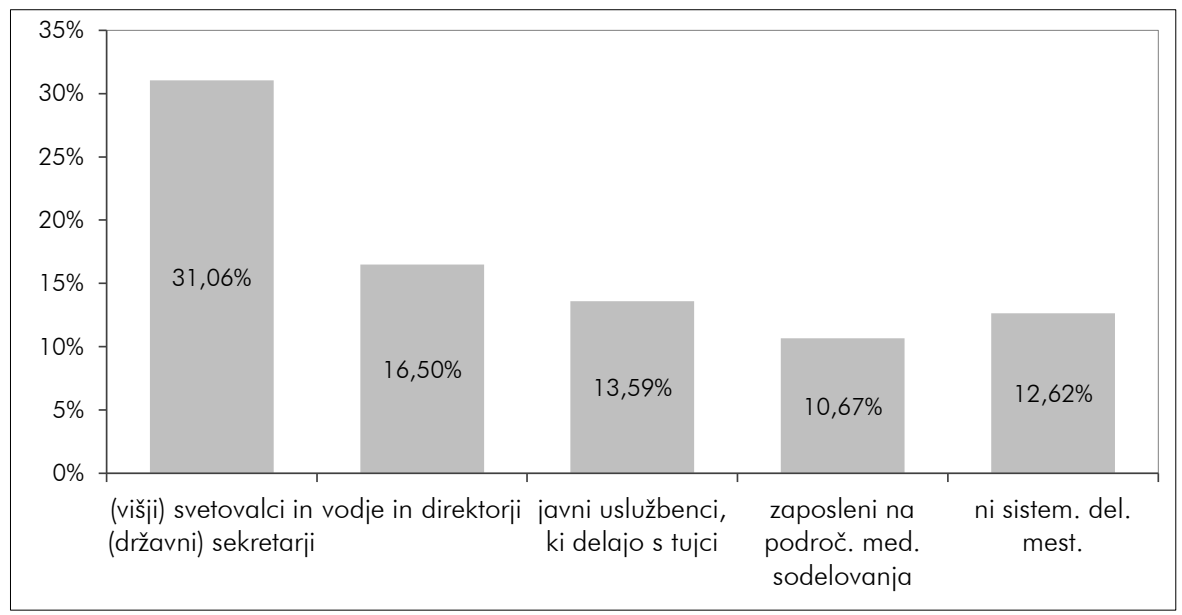

Vir: Anketa, 2009

Z analizo podatkov nismo mogli ugotoviti, ali so se potrebe javnih uslužbencev po znanju tujih jezikov po vstopu Slovenije v EU dejansko povečale. Izvedeli smo le, da je med leti 2006 in 2007 za tretjino več organizacij izobraževalo in usposabljalo svoje zaposlene na področju tujih jezikov kot v obdobju od začetka 2008 do sredine 2009. Glede napovedi do konca 2010 bi se moralo njihovo število podvojiti, kar je glede na gospodarsko in finančno situacijo vprašlijivo.

Pomenljiv rezultat kaže tudi dejstvo, da polovica respondentov (44 od 103 ali $42,71 \%$ ) ni odgovorila na vprašanje glede potreb na posameznih vsebinskih področjih. Tisti, ki so nani odgovorili $(57,25 \%)$, so navajali različna vsebinska področja, ki smo jih zaradi lažje interpretacije združili v naslednje tematske sklope: razpisi EU, zakonodaja EU, mednarodno sodelovanje, pravni jezik, izdajanje odločb tujcem (npr. $v$ zvezi z državljanstvom), splošna komunikacija s tujci, protokol in turizem. Raziskava je pokazala, da zaposleni $v$ javni upravi najpogosteje uporabljajo tuji jezik, ko se prijavljajo na razpise EU $(30,5 \%)$, spremliajo evropsko zakonodajo $(25,42 \%)$ in v okviru mednarodnega sodelovanja $(16,94 \%)$, ko gre za vodenje mednarodne delovne skupine ali komunicirajo s pobratenimi občinami. 


\section{Grafikon 4: Potrebe glede na vsebinska področja dela}

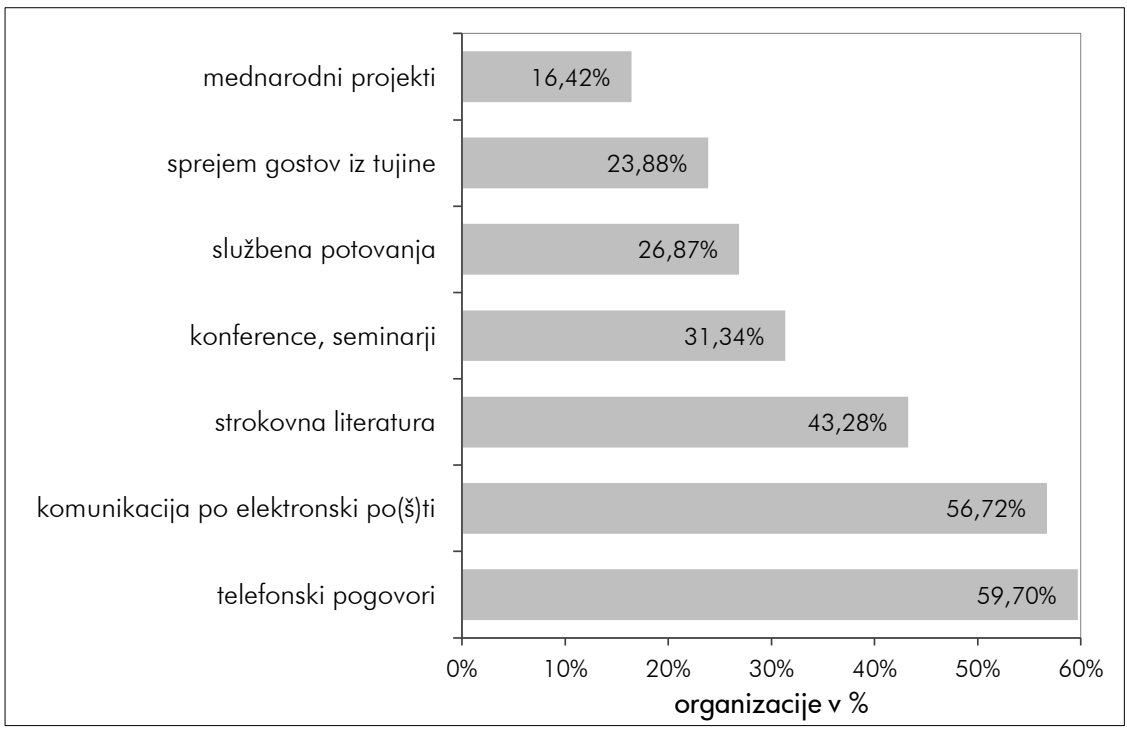

Vir: Anketa, 2009

Rezultati raziskave tudi kažejo, da javni uslužbenci pogosteje potrebujejo znanje tujega jezika s pravnega področja (15,25\%; prim. npr. za italijanščino in madžarščino Šturm et al., 2011) in pri komunikaciji s strankami iz tujine, npr. ko gre za izstavitev odločb v zvezi s pridobitvijo državljanstva ali nakup nepremičnin (13,55\%). Polega tega ga uporabljajo še na področju protokola, turizma, davkov in razvoje upravne stroke. $\vee$ okviru poslovne komunikacije (grafikon 4) najpogosteje uporabljajo tuji jezik, ko se pogovarjajo po telefonu s tujino $(59,70 \%)$, pišejo elektronsko pošto $(56,72 \%)$ in prebirajo strokovno literaturo (43,28\%).

Analiza je pokazala (grafikon 5), da dobra polovica respondentov (60 oz. $58,3 \%$ zaposlenim omogoča izpopolnjevanje in usposabljanje na področju tujih jezikov. Med njimi je največ upravnih enot (15 oz. 75 \%), organov $v$ sestavi ministrstev (14 oz. 73,68\%) in ministrstev (10 oz. $66,66 \%)$. Čeprav so rezultati pokazali (gl. grafikon 2), da zaposleni v občinskih upravah pri svojemu delu najpogosteje potrebujejo znanje angleščine $(85,71 \%)$ in nemščine $(75 \%)$, več kot polovica anketiranih občinskih uprav (15 oz. 53,57 \%) izobraževanja na področju tujih jezikov zaposlenim ne omogoča. 
Margit Horvath, Manica Danko, Polonca Kovač, Janez Stare

Tujejezikovno izobraževanje - analiza potreb in praks

tujejezikovnega izobraževanja v slovenski javni upravi

\section{Grafikon 5: Kdo javnim uslužbencem omogoča tujejezikovno izobraževanje?}

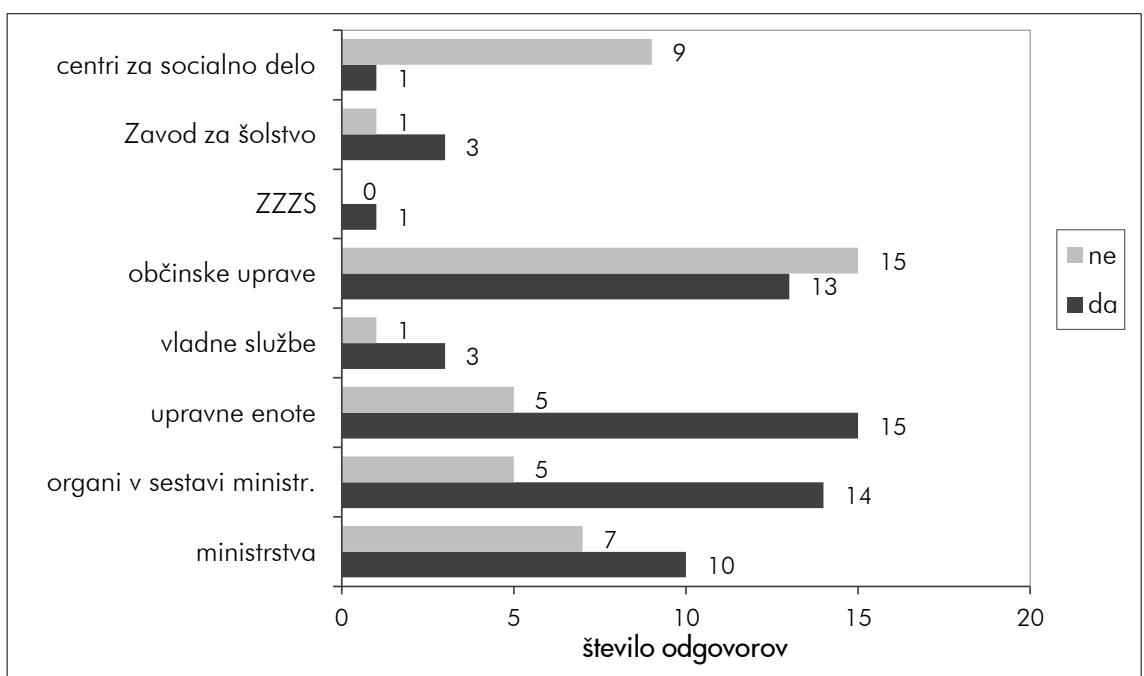

Vir: Anketa, 2009

Informacije o usposabljanju javnih uslužbencev na področju tujih jezikov zbira le dobra polovica anketirancev, od katerih večina ugotavlja tovrstne potrebe zaposlenih (grafikon 6) na osnovi letnih razgovorov (36 oz. $53,73 \%)$. Manjši delež organizacij (11 oz. $16 \%$ ) ugotavlja potrebe zaposlenih po znanju tujih jezikov na osnovi vprašalnikov ali v skladu z odredbo nadrejenih. 30 \% organizacij v javni upravi (20), ki so odgovorili na to vprašanje, tovrstnih potreb svojih zaposlenih sploh ne ugotavlja.

\section{Grafikon 6: Ugotavljanje potreb po tujejezikovnem izobraževanju}

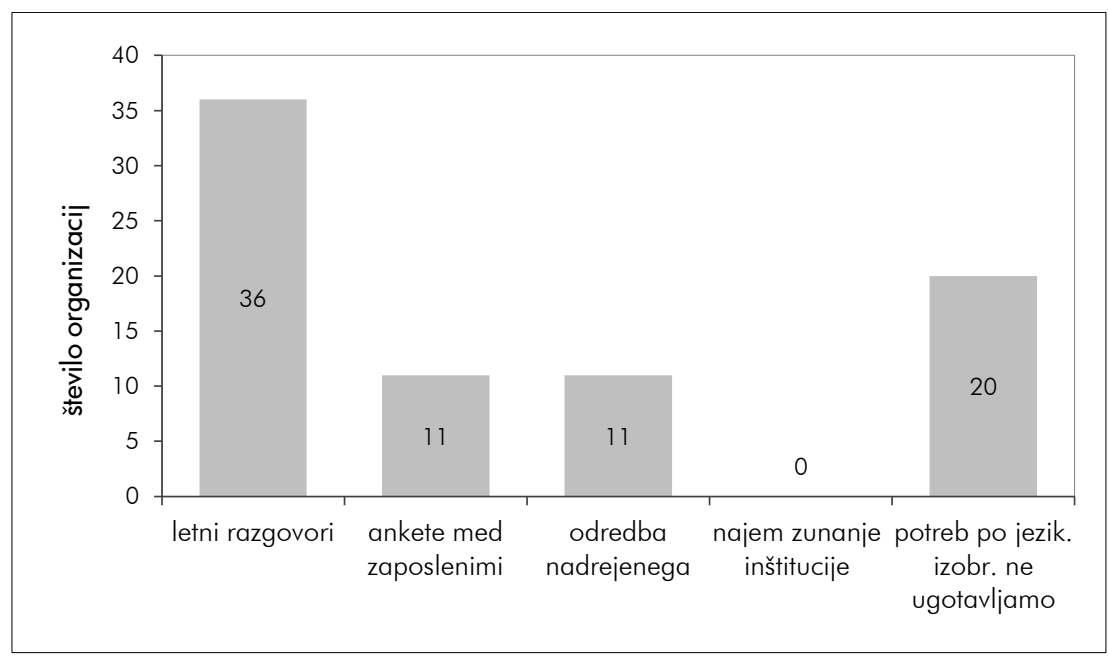

Vir: Anketa, 2009 
$\mathrm{Na}$ načrłovanje tujejezikovnega izobraževanja zaposlenih $\vee$ javni upravi najboli vplivajo (grafikon 7) stopnja zahtevnosti delovnega mesta $(95,24 \%)$ in njihove želje ter pripravljenost po jezikovnem izpopolnjevanju $(90,48 \%)$. Pomemben dejavnik pri odločanju glede izvedbe jezikovnega tečaja za zaposlene predstavljajo tudi finančna sredstva, s katerimi organizacija razpolaga $(85,71 \%)$. Jezikovne tečaje za zaposlene izvajajo tudi, vendar redkeje, na osnovi izobraževalne politike organizacije in odredbe predpostavlienega.

\section{Grafikon 7: Načrtovanje tujejezikovnega izobraževanja v javni upravi}

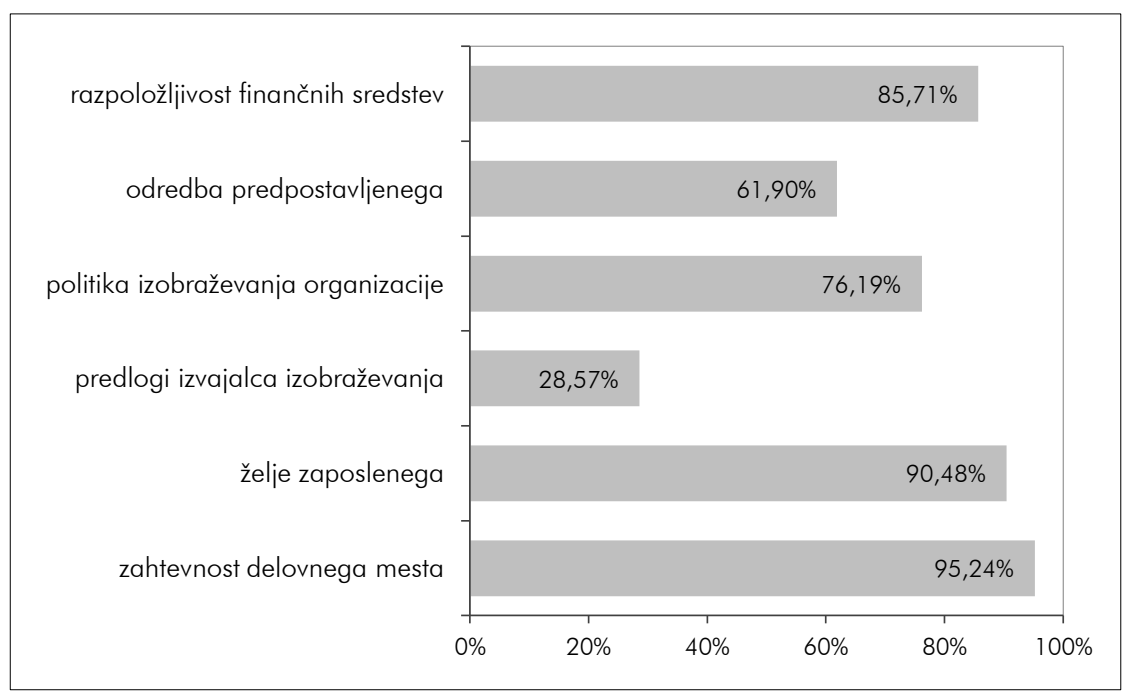

Vir: Anketa, 2009

Večina organizacij $v$ javni upravi, ki zaposlenim omogoča izobraževanje na področju tujih jezikov $(80,95 \%)$ stroške za tečaje $v$ celoti krije. Manj kot deset odstotkov organizacii zaposlenim povrne le del stroškov, medtem ko enak delež organizacij stroškov tujejezikovnega izobraževanja zaposlenim ne krije. Večina anketirancev je odgovorila, da se potrebe po tujih jezikih in tujejezikovnem izobraževanju v javnem sektorju povečujejo. $27 \%$ organizacii meni, da se te potrebe ne spreminjajo, medtem ko je $3,2 \%$ organizacij prepričana, da se zmanjšujejo.

Med zaposlenimi $v$ javnem sekłorju, ki se izobražujejo na področju tujih jezikov, je največ potreb po tečajih splošnega jezika (glede na težavnostne stopnje) in konverzaciji. Specializirane jezikovne tečaje potrebujejo za usvojitev uradniškega jezika, strokovne terminologije s področja davkov, EU predpisov, skladov in razpisov, pravne terminologije, strokovnih 
izrazov s področja dela, zaposlovanja, varnosti in zdravja pri delu, pogajani in priprav na razpise ter dela s strankami iz tujine, npr. pri urejanju matičnih zadev, izdaji vozniških dovoljenj in registraciji vozil največ iz angleškega (42,86\%), nemškega jezika $(23,81 \%)$ ter drugih jezikov kot so madžarščina, hrvaščina in srbščina $(19,04 \%)$.

Le tretjina anketiranih organizacii $v$ javni upravi (67 oz. 34,30\%) organizira tečaje tujih jezikov za zaposlene, ki potekajo $v$ večini organizacij $(71,4 \%)$ med delovnim časom. Tečaje tujih jezikov izven delovnega časa organizira $28,6 \%$ organizacii.

Grafikon 8: Koliko zaposlenih je vključeno v tujejezikovno izobraževanje?

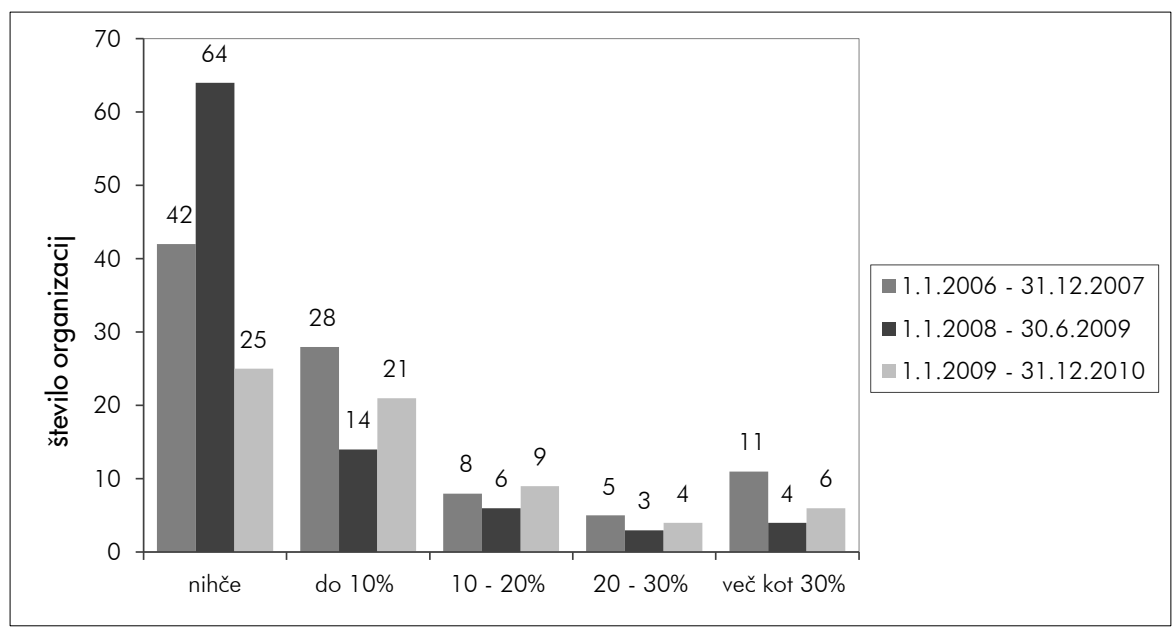

Vir: Anketa, 2009

Pri odgovoru na vprašanje o številu zaposlenih vključenih v tujejezikovno izobraževanje (grafikon 8) so opazna precejšnja odstopanja med posameznimi obdobji. Med respondenti je največ organizacii, ki v tujejezikovno izobraževanje vključujejo do $10 \%$ zaposlenih. V obdobju od začetka 2006 do konca 2007 je bilo za tretjino več organizacii, ki so omogočile zaposlenim izobraževanje na področju tujih jezikov, kot $v$ času od začetka 2008 do sredine 2009. Razlogi za to so lahko intenzivnejše priprave Slovenije na predsedovanje Sveta EU (od 1. 1. do 30. 6. 2008).

Ugotovili smo, da je povprečno število ur tujejezikovnega izobraževanja na zaposlenega bilo najnižje $v$ obdobju od začetka 2008 do polovice 2009 (38) in za $3 \%$ nižje od povprečja v obdobju od začetka 2006 do konca 2007 (41). Napovedi respondentov glede tujejezikovnega 
izobraževanja zaposlenih do konca 2010 so bile precej optimistične ${ }^{14}$, čeprav je zaradi poglobitve gospodarske in finančne krize, ki je zajela tudi javni sektor, zelo verjetno, da je tega izobraževanja bilo še manj.

Od 21 anketirancev, ki organizirajo jezikovne tečaje za zaposlene ( $g$ l. grafikon 5), je večina $(76,20 \%)$ odgovorila, da jezikovni tečaji potekajo v skupinah z več kot 8 udeležencev. V 4 organizacijah (19\%) so skupine manjše in imajo največ do 6 slušateljev. $O$ izobraževanju $v$ skupinah $\mathrm{s}$ tremi in mani slušateliev sta poročali le dve organizaciji (9,5\%). Nismo zasledili individualnega pouka, čeprav smo pričakovali, da se za vodilne kadre (npr. vodje in direktorje) izvajajo tečaji po meri, ki so vsebinsko in časovno prilagojeni nijhovemu delu.

Zaposleni v večini anketiranih organizacij (16 oz. 76,19\%) obiskujejo tečaje tujih jezikov, ki potekajo več mesecev letno z manj ur na teden. Zaposleni v 19,04\% organizacii (4) imajo intenzivne jezikovne tečaje, ki se izvajajo $v$ daljšem časovnem obdobju in $z$ več ur pouka dnevno. $\bigcirc$ eno- ali dvodnevnih delavnicah $\vee$ tujem jeziku je poročala le ena organizacija.

\section{Grafikon 9: Oblike tujejezikovnega izobraževanja}

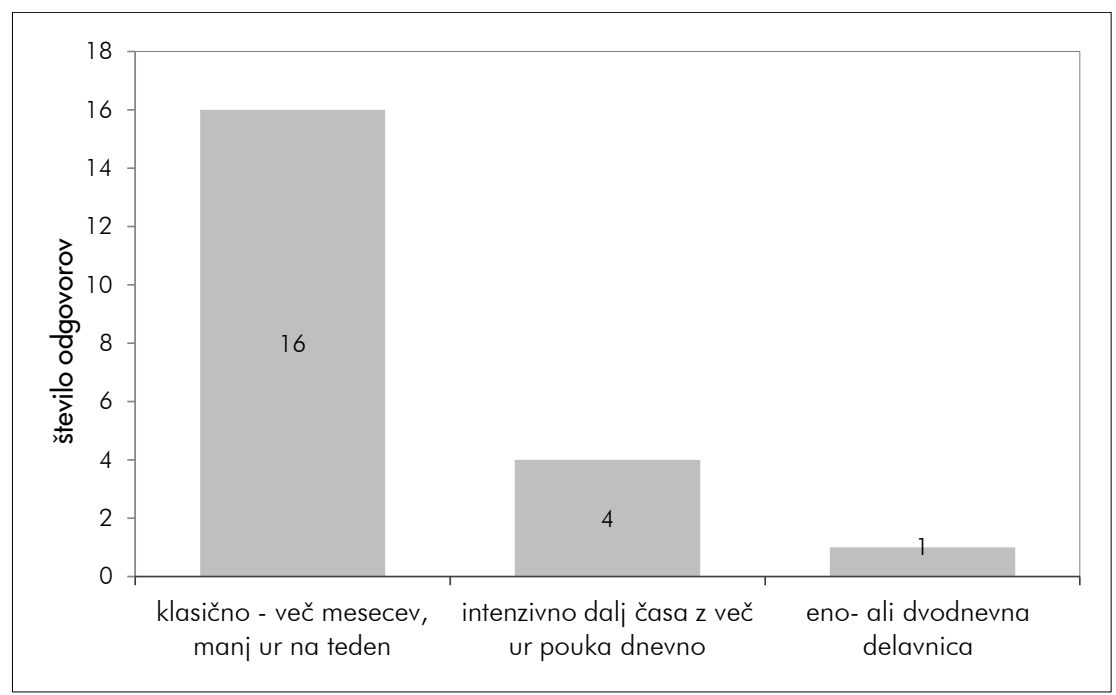

Vir: Anketa, 2009

Od 64 anketirancev $(62,13 \%)$, ki so odgovorili na vprašanje o povezavi med potrebami zaposlenih po znanju tujega jezika in izboljšanju kakovosti

14 Povprečno število ur naj bi se zvišalo na 46. 
upravnih postopkov, igra po mnenju večine $(78,12 \%)$ znanje tujega jezika pomembno vlogo pri izboljšanju kakovosti storitev. Preostalih 21,87\% meni, da kakovost storitev ni odvisna od znanja tujih jezikov njihovih zaposlenih. Večina med njimi je navedla (prim. Jerovšek \& Kovač, 2010), da znanje tujega jezika ni potrebno za večino delovnih mest $v$ javni upravi.

\section{Grafikon 10: Razlogi povečevanja tujejezikovnih potreb}

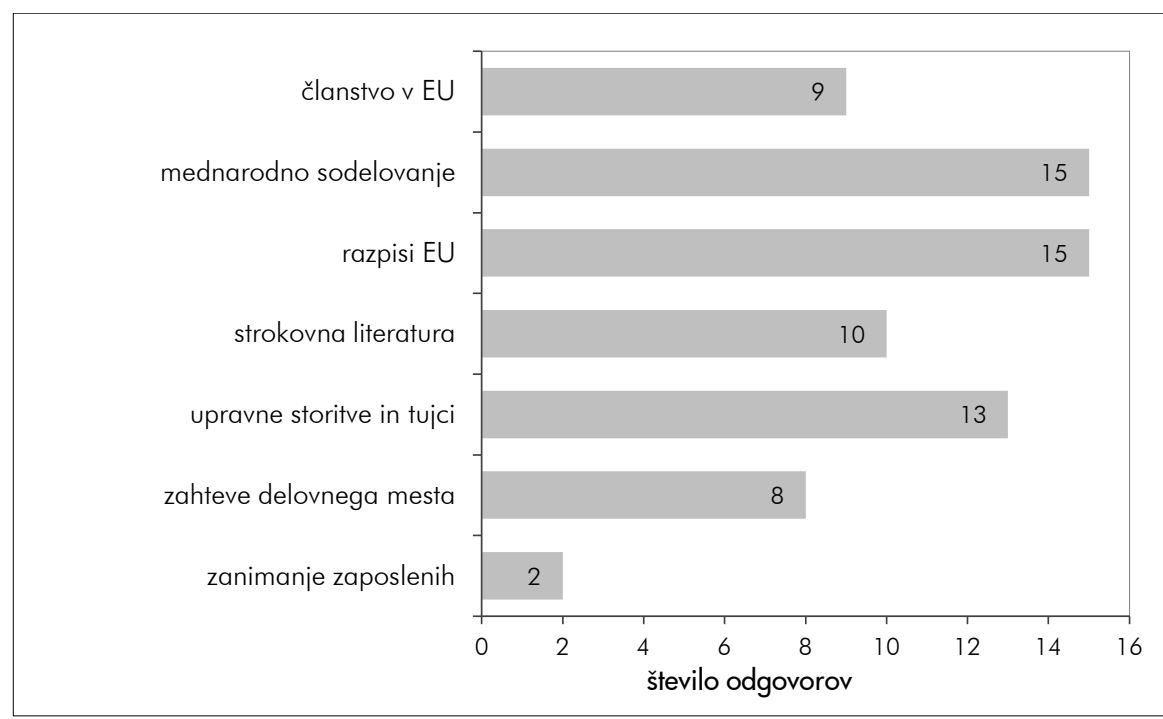

Vir: Anketa, 2009

Med 67 anketiranci je večina prepričana, da so glavni razlogi za povečanje potreb po znanju tujih jezikov (grafikon 10) mednarodno sodelovanje in razpisi EU. Med pomembnimi razlogi so tudi upravne storitve in delo s tujci, ki so se priselili v Slovenijo. $10 \%$ anketirancev meni, da je obvezno branje tuje strokovne literature tudi eden od razlogov za povečane potrebe po tujejezikovnem izobraževanju.

\section{Preveritev hipotez}

Raziskava na področju tujejezikovnega izobraževanja javnih uslužbencev v slovenskem prostoru je potrdila le eno hipotezo $v$ celoti, večino ostalih pa le delno. Zaradi nizke realizacije raziskovalnega vzorca ene hipoteze ni bilo možno preveriti. Gre za hipotezo, ki se nanaša na razliko v potrebah po znanju tujega jezika $v$ javni upravi med posameznimi statističnimi regijami in organizacijami. Ta primerjava žal ni bila mogoča, ker so trije 
javni zavodi (ZZZS, Zavod za šolstvo, CSD) zastopani $v$ raziskovalnem vzorcu s premajhnim številom oz. dva (ZPIZ, ZRSZ) sploh nista zastopana.

Raziskava je delno ovrgla hipotezo, da znanje tujih jezikov (angleščine in nemščine) največ potrebujejo na zunanjem ministrstvu. Znanje obeh jezikov največ potrebujejo zaposleni v skoraj vseh ministrstvih in $v$ organih $\checkmark$ njihovi sestavi ter na občinskih upravah in upravnih enotah (predvsem $v$ statističnih regijah $v$ bližini avstrijske meje).

Raziskava je potrdila hipotezo, da javni uslužbenci imajo potrebe po znanju angleškega (83 \%) oz. nemškega jezika (68 \%) ter hrvaškega oz. srbskega jezika zaradi priseljevanja državljanov z območja nekdanje Jugoslavije. Znanja tujih jezikov ne potrebujejo le vodilni kadri, temveč tudi svetovalci, višji svetovalci, sekretarii in državni sekretarji ter javni uslužbenci pri uradnem delovanju s tujci in zaposleni na področju mednarodnega sodelovanja. Z analizo žal nismo mogli ugotoviti, ali so se potrebe javnih uslužbencev po znanju tujih jezikov po vstopu Slovenije v EU dejansko povečale.

Raziskava je potrdila hipotezo, da so vsebinska področja, kjer so potrebe po učenju tujega jezika največje, povezana s sodelovanjem Slovenije z EU. Zaposleni v javni upravi najpogosteje potrebujejo znanje tujega jezika zaradi prijar na razpise EU, spremljanja evropske zakonodaje in mednarodnega sodelovanja (npr. pri vodenju mednarodnih delovnih skupin ali pri komuniciranju s pobratenimi občinami). Poleg tega javni uslužbenci uporabljajo tuji jezik tudi $\vee$ drugih situacijah, vendar redkeje: npr. na področju pravnega jezika, davkov in razvoja stroke, pri protokolu ali komunikaciji s strankami iz tujine (ko gre za izstavitev odločb v zvezi s pridobitvijo državljanstva ali nakup nepremičnin) in v turizmu.

Rezultati raziskave so $v$ celoti potrdili hipotezo, da usposablianje in izpopolnjevanje javnih uslužbencev na področju tujih jezikov ni stalno, sistematično in za vse enako. Skoraj polovica anketiranih organizacij v javni upravi tujejezikovnega izobraževanja in usposabljanja zaposlenim sploh ne omogoča, medtem ko tečaje tujih jezikov za javne uslužbence organizira le tretjina anketirancev. Načrtovanje tujejezikovnega izobraževanja za zaposlene je predvsem odvisno od delovnega mesta, želje zaposlenih in razpoložliivosti finančnih sredstev. Na odločitve vplivata tudi politika organizacije na področju (jezikovnega) izobraževanja in odredba predpostavljenega. Skoraj tretjina organizacii potreb zaposlenih po znanju tujih jezikov sploh ne ugotavlia. 
Analiza rezultatov je ovrgla hipotezo, da organizacije $v$ javni upravi tečajev tujih jezikov za zaposlene ne financirajo. Velika večina organizacii zaposlenim plača tečaje tujih jezikov $v$ celoti.

Med zaposlenimi $v$ javnem sektorju so največje potrebe po tečajih splošnega jezika po stopnjah in tečajih konverzacije. Specializirane tečaje potrebujejo za usvojitev uradniškega jezika, strokovne terminologije s področja davkov, EU predpisov, skladov in razpisov, pravne terminologije, strokovnih izrazov s področja dela, zaposlovanja, varnosti in zdravja pri delu, pogajanj in priprav na razpise ter dela s strankami iz tujine (pri urejanju matičnih zadev, izdaji vozniških dovoljenj in registraciji vozil). Specializirane tečaje angleščine potrebuje skoraj za polovico več organizacii (43\%) kot specializirane tečaje nemščine (24\%).

Zaposleni v večini organizacij, ki omogočajo tujejezikovno izobraževanje, obiskujejo tečaje tujih jezikov več mesecev na leto, ki potekajo le nekaj ur tedensko. Intenzivni tečaji se izvajajo $v$ daljšem časovnem obdobju $z$ več ur pouka dnevno. Eno- ali dvodnevne delavnice $v$ tujem jeziku se skoraj ne izvajajo. $\vee$ večini organizacii potekajo tečaji tujih jezikov med delovnim časom.

Večina anketirancev je odgovorila, da se potrebe po tujih jezikih in tujejezikovnem izobraževanju v javnem sekłorju povečujejo. $27 \%$ organizacij je menilo, da se te potrebe ne spreminjajo, medtem ko je 3,2\% organizacij izrazila prepričanje, da se le-te zmanjšujejo.

\section{Zaključek}

Slovenska javna uprava je bila ves čas, še posebej pa zadnja leta izpostavliena različnim oblikam tujejezikovnih potreb. Največ nijh ima vzrok $v$ zgodovinskih (bivša država), političnih (osamosvojitev) in strukturnih spremembah (EU). Še posebej vpetost $v$ evropske tokove in marsikdaj "življenjska" odvisnost od evropskih direktiv in razpisov vse pomembneje zaznamujeta delovanje javnih uslužbencev. Kljub temu pa je zavedanje o potrebi tujejezikovnega poslovanja $v$ javni upravi razmeroma nizko. Verjetno je s tem povezano tudi dejstvo, ugotovljeno $v$ raziskavi, da ni ozaveščenosti zaposlenih $\vee$ javni upravi glede pomena in prednosti znanja tujih jezikov pri opravljanju delovnih nalog.

To dejstvo potrjuje ugotovitev, da pri nas $v$ javnosti še vedno prevladuje prepričanje, da znanje tujih jezikov ni ključnega pomena za kakovostno 
opravljanje delovnih nalog javnih uslužbencev, ki so večinoma povezane z domačim prebivalstvom. Toda raziskava je pokazala drugačno sliko.

$\checkmark$ gospodarstvu se zavedajo pomena tujih jezikov za uspešno komunikacijo in sodelovanje na različnih področjih. Vedno več podjetii si prizadeva izbolišati jezikovno znanje zaposlenih, ker je tesno povezano s sposobnostjo za internacionalizacijo ter je eno od najpomembnejših orodii za doseg pomembnih poslovnih in znanstvenih informacii ter dodatnih finančnih virov (npr. iz evropskih skladov). Tudi Evropska komisija poudarja pomen večjezičnosti za poslovno uspešnost na globalnem trgu. Poleg angleščine, ki je ohranila vlogo vodilnega svetovnega jezika, so še drugi jeziki odločilni za razlikovanje med povprečjem in odličnostjo in prinašajo konkurenčno prednost.

$\checkmark$ tem duhu bi tudi država morala ravnati kot gospodaren delodajalec in večjezičnosti pripisati večji pomen. $V$ našem sobivanju $z$ drugimi državami unije znanje tujih jezikov ni le most do drugih evropskih kultur, temveč odpira tudi veliko možnosti za nove poslovne priložnosti za organizacije v javni upravi. Javni uslužbenci ne potrebujejo znanja tujih jezikov le zaradi uspešnega poslovanja s strankami iz tujine, temveč tudi kot pomembno orodje za povezovanje z zunanjimi "trgi" in dobičkonosno poslovanje $s$ pomočjo evropskih projektov.

Margit Horvath se je poleg študija anglistike in germanistike na Filozofski fakulteti v Ljubliani izpopolnjevala na univerzi v Heidelbergu in Gradcu na področju nemščine kot tuji jezik. Leta 2002 je končala na Donavski univerzi v Kremsu magistrski študij s področja ekonomije in menedžmenta "Executive MBA". Nieno raziskovalno delo je usmerieno na primerjalno analizo nemško-slovenskih besedil na področju ekonomskih in upravnih znanosti in dvig kakovosti poučevanja tujega jezika. Na Fakulteti za upravo je zaposlena kot višja predavateliica za nemški jezik.

Manica Danko je lektorica angleškega strokovnega jezika na Fakulteti za upravo. Magisterij TESOL je zaključila na University of Manchester s tematiko oblikovanja visokošolskih tujejezikovnih učbeniških gradiv. Raziskuje na področju kakovosti poučevanja tujih jezikov in medpredmetnega povezovanja v visokem šolstvu ter je avtorica učbeniških gradiv. 
Margit Horvath, Manica Danko, Polonca Kovač, Janez Stare

Tujejezikovno izobraževanje - analiza potreb in praks

tujejezikovnega izobraževanja v slovenski javni upravi

Dr. Polonca Kovač je raziskovalka in visokošolska učiteljica na področjih pravne ureditve in reform javne uprave ter upravnega procesnega prava. Doktorirala je leta 2005 na Pravni fakulteti v Ljubljani. Je (so)avtorica in urednica vrste monografij (npr. Presoja učinkov regulacije 2009, Upravni postopek in upravni spor, 2010, Razvoj slovenske javne uprave 1991$2011)$ in prispevkov $v$ periodiki ter na znanstvenih in strokovnih konferencah doma in $v$ tujini.

Dr. Janez Stare je zaposlen kot docent za področje organizacije javnega sektorja na Fakulteti za upravo Univerze v Ljubljani. Poleg nosilstva predmetov na 1. in 2. stopnii študija opravlia tudi dela in naloge prodekana za študijske zadeve ter predstojnika katedre za organizacijo in informatiko. Težišče njegovega raziskovalnega, pedagoškega in svetovalnega dela je povezano z vodenjem, ravnanjem z ljudmi in organiziranjem. Svoje strokovno znanje je izpopolnjeval doma in na uglednih institucijah v tujini. Kot vodja ali sodelavec sodeluje $v$ različnih projektih ter na strokovnih in znanstvenih srečanjih. Od leta 2011 je predsednik Uradniškega sveta. 


\section{Literatura in viri}

- Bundesministerium für Unterricht, Kunst und Kultur (BMUKK), Österreich, Schlick, Klaus, Diskussionsforum 4, (2010). Mobilität und Fremdsprachen in einem europäischen Bildungsraum ohne Grenzen, 1-15. Pridobljeno 30. 1. 2012, s http://www.bmukk.gv.at/medienpool/8169/Forum4.pdf.

- Čebron, N. (1998). Status quo of ESP at the tertiary education level in Slovenia - a focus on the University of Liubliana. V: Čebron, N. (ur.). New challenges in teaching ESP in Slovenia / IATEFL Slovenia, lst National ESP Conference (23-31), Portorož, 11-13 June 1998.

- Danko, M., Stare, J. \& Horvath, M. (2009). Analiza in ugotavlianje potreb študentov in diplomantov Fakultete za upravo (FU/NUŠ) na področju jezikovnega izobraževanja oz. pri predmetih angleški in nemški jezik.

- Diurić, M. (1999). Kako lahko preoblikujemo tradicijo ESP/EAP v Sloveniji. Vestnik 33(1-2), 7-22.

- Djurić, M. et al. (2008). Tuji jeziki stroke v slovenskem visokem šolstvu: poimenovanje, ravni, obseg, cilji in učna gradiva. V: Skela, J. (ur.). Učenje in poučevanje tujih jezikov na Slovenskem (523-525). Ljubljana: Tangram.

- EC.EUROPA (2009). Languages of Europe. Pridobljeno 30. 8. 2009, s http://ec.europa.eu/education/languages/languages-of-europe/ doc135_en.htm.

- Education and Training 2020 (ET 2020). The Council of Europe, (2009). Pridoblieno 30.1.2012, s http://europa.eu/legislation_summaries/ education_training_youth/general_framework/c1 1086_en.htm.

- Erbič D. (2008): Jezikovna ureditev Evropske unije in posledice članstva v EU za slovenski jezik. V: Ivšek, M. (ur.) Jeziki v izobraževanju. Zbornik prispevkov konference (107-1 10), Ljubljana, 25.-26. septembra 2008. Ljubljana: Zavod RS za šolstvo.

- Goethe Institut (GI) Ljubljana, (2009). Razlogi za učenje nemščine, pogovor s Hansom-Jürgenom Krummom. Pridoblieno 24. 1. 2012, s http://www.goethe.de/ins/si/liu/lhr/liu_lhr_gruende/sl4568512.htm.

- Goethe-Institut (GI). Der gemeinsame Europäische Referenzrahmen in seinem politischen und bildungspolitischen Kontext, Was bedeutete Mehrsprachigkeit? Pridoblieno 24. 1. 2012, s http://www.goethe.de/z/50/commeuro/.

- Grmek, A. \& Rejec, S. (2005). Nemščina v slovenskem visokošolskem prostoru. Pridoblieno 3. 8. 20009, s http://www2.arnes.si/ sdunil/ SCHAUREIN_18_povzetki.pdf.

- Horvath, M. (2008). Studienbegleitender Deutschunterricht in Slowenien. V: Lévy-Hillerich, D. \& Serena, S. (ur.). Studienbegleitender Deutschunterricht in Europa. Rückblick und Ausblick: Versuch einer Standortbestimmung (372414), Roma: Lingue d’Europa e del Mediterraneo, Aracne Editrice (izdano 2009).

- Jakoš, Z. (2007). The role of ESP in the newly developed Bologna study programmes at Slovene faculties. In Graf, E.-M. \& James Allen (ur.). English studies in flux (149-157). Tübingen: Gunter Narr Verlag. 
Margit Horvath, Manica Danko, Polonca Kovač, Janez Stare

Tujejezikovno izobraževanje - analiza potreb in praks

tujejezikovnega izobraževanja v slovenski javni upravi

- Jerovšek. T. \& Kovač, P. (2010). Upravni postopek in upravni spor. Ljubliana: Fakulteta za upravo.

- Jurković, V. et al. (2008). Status učitelja tujega jezika stroke v visokem šolstvu. V: Inter alia, zbornik prispevkov s posveta SDUTSJ (23. 11 .2007).

- Jurković, V. \& Djurić, M. (2008): Tuji jeziki stroke v slovenskem visokem šolstvu. V: Ivšek, M. (ur.). Jeziki v izobraževanju. Zbornik prispevkov konference (215-222), Ljubljana, 25.-26. September 2008. Ljubljana: Zavod Republike Slovenije za šolstvo.

- Komac, M. (2007). Priseljenci, Študije o priseljevanju in vključevanju v slovensko družbo. Inštitut za narodnostna vprašanja.

- Kovač, P., Rakar, I. \& Remic, M. (2012): Upravno-procesne dileme o rabi ZUP, 2. del - vprašanja iz prakse z odgovori, sodno prakso in uvodno študijo ( $v$ tisku). Ljubljana: Uradni list RS.

- Ministrstvo Republike Slovenije za šolstvo in šport (MSS), Skupni evropski jezikovni okvir: učenje, poučevanje, ocenjevanje, (2011). Pridobljeno 24. 1. 2012, s http://www.mss.gov.si/fileadmin/mss.gov.si/pageuploads/ podrocje/razvoi_solstva/Jeziki/Publikacija_SEJO_komplet.pdf.

- Nancy Declaration. Multilingual Universities for a Multilingual Europe Open to the World, (2006). Pridobljeno 30. 1. 2012, s http://www.campuseuropae.org/en/support/docs/langlearning/enlu_nancy declaration.pdf.

- Pregled posledic odsotnosti skladne tujejezikovne politike na vseh ravneh izobraževanja v RS ter predlogi za izboljšavo ugotovljenega stanja.

Pridobljeno 16.1.2012, s http://www.sdutsi.edus.si/tujejezikovna_politika.html.

- Statistični urad Republike Slovenije (2011). Selitveno gibanje, 2009, končni podatki. Pridoblieno 24. 1. 2012, s http://www.stat.si/novica_prikazi.aspx?id=3362.

- Stare, J. (2007). Rezultat dela na projektu v okviru ciljno raziskovalnega programa (CRP) »Konkurenčnost Slovenije2006-2013«, Naslov projekta: Določitev kompetenc zaposlenih v javni upravi. Pridobljeno 24. 1. 2012, s http://www.mju.gov.si/fileadmin/mju.gov.si/pageuploads/mju_dokumenti/D OK/dolocitev_kompetenc_zaposlenih_v_javni_upravi.pdf.

- Šturm, L. (ur.) et al. (2011). Komentar Ustave Republike Slovenije-dopolnitev A. Brdo: Fakulteta za državne in evropske študije.

- Svetličič, M. (2011a). Kompetence za ekonomsko diplomacijo in mednarodno poslovanje; konvergenca ali divergenca? Uprava 9(1), 123-141.

- Svetličič, M. (2011 b). Diplomacija in mednarodno poslovanje v 21. stoletju: komplementarnost ali nadomestnost. Teorija in praksa 48(3), 604-627.

- Svetlin-Gvardjančič, P. et. al (2009). Strani jezik struke u bolonjskom procesu: status predmeta in organizacija nastave. (str. 721-735). V: Vučo, J., Ignjačević, A. \& Mirić, M.(ur.). Jezik struke: Teorija i praksa. Zbornik radova. Univerzitet u Beogradu.

- Ustava RS, Ur. I. RS, št. 33/91-1, 42/97, 66/04. 
- Verlič Christensen, B. (2000). Migracijska politika Evropske skupnosti in Slovenija. Teorija in praksa 37(6), 1117-1131. Pridobljeno 30. 8. 2009, s http://dk.fdv.uni-li.si/tip/tip20006verlicchristensen.PDF.

- Zakon o javni rabi slovenščine Ur. I. RS, št. 86/04.

- Zakon o splošnem upravnem postopku (ZUP), Ur. I. RS, št. 80/99 in nasl.

- Zavašnik, M. (2006). Analiza potreb učiteljev angleškega strokovnega jezika z vidika nïhovih specifičnih sposobnosti v okviru usposabljanja in izpopolnjevanja. Neobjavljen doktorat. Ljubljana: Filozofska fakulteta. 